\title{
Simulation model of land cover changes in a post-socialist peripheral rural area: Požega-Slavonia County, Croatia
}

\section{Simulacijski model promjena zemljišnog pokrova u postsocijalističkom perifernom ruralnom području: Požeško-slavonska županija, Hrvatska}

Simulation modelling is a useful method for the explanation and prediction of land use and land cover changes, which are fundamentally interconnected with broader social and natural elements. Significant land cover changes, predominantly land abandonment, occurred in peripheral rural areas across Central and Eastern Europe after the collapse of socialism. One such area is Požega-Slavonia County in Croatia, for which we modelled land cover changes from 1985 to 2027. The prevailing change from 1985 to 2013 was secondary succession. The simulation model of future land cover changes was based on cellular automata and artificial neural networks, and was implemented in the MOLUSCE plugin for QGIS. Validation of the test models showed that they more successfully predicted the quantity (rather than the location) of the changes, and the post-simulation combination of individual results slightly improved their agreement with reference data. The final model predicted that forests would cover over $60 \%$ of the whole area by 2027 if the current negative demographic and economic trends continue into the future.

Key words: artificial neural networks, cellular automata, land use and land cover change, peripheral area, simulation model, MOLUSCE
Simulacijsko modeliranje korisna je metoda za objašnjavanje i projekciju promjena načina korištenja zemljišta i zemljišnog pokrova, koje su u osnovi povezane sa širim društvenim i prirodnim elementima. Značajne promjene zemljišnog pokrova, pretežito napuštanje zemljišta, dogodile su se u perifernim ruralnim područjima diljem Središnje i Istočne Europe nakon raspada socijalizma. Jedno je takvo područje Požeško-slavonska županija u Hrvatskoj, za koju su modelirane promjene zemljišnog pokrova od 1985. do 2027. godine. Prevladavajuća promjena od 1985. do 2013. bila je sekundarna sukcesija. Simulacijski model budućih promjena zemljišnog pokrova temeljen je na ćelijskim automatima i umjetnim neuronskim mrežama i realiziran u dodatku MOLUSCE za QGIS. Validacija testnih modela pokazala je da su oni točnije predviđali kvantitetu (bolje od lokacija) promjena te da je naknadna kombinacija individualnih rezultata simulacija nešto poboljšala njihovo podudaranje $s$ referentnim podatcima. Konačni je model predvidio da bi šume mogle pokrivati više od $60 \%$ cijelog područja do 2027. ako se trenutni negativni demografski i ekonomski trendovi nastave u budućnosti.

Ključne riječi: umjetne neuronske mreže, ćelijski automati, promjene načina korištenja zemljišta i zemljišnog pokrova, periferno područje, simulacijski model, MOLUSCE 
HRVATSKI

GEOGRAFSKI

GLASNIK

81/1,31-59 (2019.)

\section{Introduction}

Land use and land cover changes (LULC) result from the complex interaction of many natural and social factors (Pijanowski et al., 2002). Understanding the causes and consequences of LULC has become critical because they impact biodiversity, carbon dynamics, climate, hydrology, and livelihoods (Memarian et al., 2012).

Global trends of LULC can be divided into two opposite categories: intensification (agricultural expansion, urbanisation, deforestation, etc.) and extensification (land abandonment, afforestation, etc.) (Díaz et al., 2011). Polarisation of these trends is the most common on agricultural land, which represents the largest terrestrial biome. There is a consensus that agricultural intensification generates land degradation and reduces the quality and quantity of the services that ecosystems provide to humanity. However, the abandonment or extensification of agriculture yields two-sided consequences (Rey Benayas et al., 2007). Negative consequences of extensification include the disappearance of traditional farming practices, long-term loss of habitats of high ecological value, higher probability of wildfires, invasion of exotic species, food insecurity (Díaz et al., 2011), reduction of biodiversity, loss of landscape identity, etc. (Ruskule et al., 2012). Some of the positive consequences are improved hydrological regulation, soil recovery and erosion mitigation, higher water quality, increased fertility, fungal biomass and decomposer activity, and carbon sequestration (Rey Benayas et al., 2007).

These consequences are not always relevant in all parts of the world or are only relevant at small scales (Rey Benayas et al., 2007). Nowadays, the biodiversity of semi-natural agricultural land in Europe is almost as valuable as wild biodiversity. A central issue of Europe's traditional cultural landscapes is their instability, i.e. their dependence on a medium degree of human impact. If land use is abandoned, traditional landscapes will be displaced by spontaneous secondary succession. Conversely, human impact that is too intensive will lead to the conversion of traditional landscapes into more simplified landscapes (Plieninger et al., 2006). Since the mid-twentieth century, European peripheral
Uvod

Promjene načina korištenja zemljišta i zemljišnog pokrova (engl. LULC) rezultat su složenog odnosa između mnoštva prirodnih i društvenih čimbenika (Pijanowski i dr., 2002). Razumijevanje uzroka i posljedica tih promjena postalo je važno jer one utječu na bioraznolikost, dinamiku ugljika, klimu, hidrologiju i život ljudi (Memarian i dr., 2012).

Globalni trendovi spomenutih promjena mogu se podijeliti na dvije suprotne kategorije: intenzifikaciju (poljoprivredna ekspanzija, urbanizacija, deforestacija itd.) i ekstenzifikaciju (napuštanje zemljišta, aforestacija itd.) (Díaz i dr., 2011). Polarizacija tih trendova najčešća je na poljoprivrednom zemljištu, najvećem svjetskom staništu. Postoji konsenzus o tome da poljoprivredna intenzifikacija uzrokuje degradaciju zemljišta te smanjuje kvalitetu i kvantitetu usluga koje ekosustavi pružaju čovječanstvu. Međutim, napuštanje ili ekstenzifikacija poljoprivrede ima dvojne posljedice (Rey Benayas i dr., 2007). Negativne posljedice ekstenzifikacije uključuju nestanak tradicionalnih poljoprivrednih djelatnosti, dugoročni gubitak staništa visoke ekološke vrijednosti, povećanu vjerojatnost šumskih požara, invaziju egzotičnih vrsta, nesigurnost hrane (Díaz i dr., 2011), smanjenje bioraznolikosti, gubitak identiteta krajolika itd. (Ruskule i dr., 2012). Neke od pozitivnih posljedica su poboljšana hidrološka regulacija, oporavak tla i sprečavanje erozije, povećanje kvalitete vode, povećana plodnost, biomasa gljiva i aktivnost razlagača te sekvestracija ugljika (Rey Benayas i dr., 2007).

Spomenute posljedice nisu jednako relevantne u svim područjima svijeta ili su relevantne u sitnim razmjerima (Rey Benayas i dr., 2007). Danas je bioraznolikost poludivljih poljoprivrednih zemljišta u Europi važna gotovo kao bioraznolikost divljine. Središnji je problem europskih tradicionalnih kulturnih pejzaža njihova nestabilnost, tj. ovisnost o umjerenom ljudskom utjecaju. Ako se zemljište napusti, tradicionalne će pejzaže zamijeniti spontana sekundarna sukcesija. Suprotno, preintenzivan ljudski utjecaj dovest će do transformacije tradicionalnih pejzaža u jednostavnije pejzaže (Plieninger i dr., 2006). Od sredine dvadesetog stoljeća europska su periferna ruralna područja izgubila dosta svoga poludivljega poljoprivrednog zemljišta, a simulacijski su modeli 
rural areas have lost much of their semi-natural agricultural land, and simulation models have predicted the continuation of this trend in the coming decades (Navarro and Pereira, 2012; Ruskule et al., 2012).

The interest in researching European peripheral areas is also visible in numerous rural typologies. Newer examples include typologies from Croatia (Lukić, 2012), the Czech Republic (Klufová, 2016), Hungary (Beluszky and Sikos, 2008), Moldavia (Tudora, 2009), Poland (Bański and Mazur, 2016), Russia (Mikhaylova et al., 2015), and Slovenia (Cosier et al., 2014). They indicate that rural areas with different developmental obstacles occupy a significant part of national territory. Although peripheral rural areas are certainly not a unique feature of Central, Eastern, and Southeast Europe, their specificity is their composition: not only remote or areas with natural disadvantages but also the so-called internal rural peripheries (TA, 2011). This unique type of countryside is described as an area with poor accessibility and scarcity of more developed urban central settlements. Many of them are characterised by weak local economies and lack of job opportunities for young people. Negative demographic processes progress, particularly out-migration and ageing of the population (TA, 2011). As a consequence, land is usually abandoned, resulting in secondary succession and afforestation.

Although rural depopulation had already started in $19^{\text {th }}$ century in karst peripheral areas, the origin of systematic problems in Croatian rural areas can be traced to the socialist period. General and agrarian policies became unfavourable for farmers' private properties, which, along with long-term depopulation, deagrarianisation, and pauperisation, resulted in their social and economic impoverishment. The Croatian War of Independence and the collapse of socialism in the 1990's caused massive socio-economic and institutional changes (Lukić, 2012). The period of transition to a market economy was characterised by economic crisis, depopulation, unsuccessful privatisation, and deterioration of the sectoral structure (Pejnović and Kordej-De Villa, 2015). The aforementioned conditions and processes influenced land abandonment and afforestation (Cvitanović et al., 2016). predvidjeli nastavak toga trenda u idućim desetljećima (Navarro i Pereira, 2012; Ruskule i dr., 2012).

Zanimanje za istraživanje europskih perifernih područja također je uočljivo u brojnim ruralnim tipologijama. Noviji primjeri uključuju tipologije iz Hrvatske (Lukić, 2012), Češke (Klufová, 2016), Mađarske (Beluszky i Sikos, 2008), Moldavije (Tudora, 2009), Poljske (Bański i Mazur, 2016), Rusije (Mikhaylova i dr., 2015) i Slovenije (Cosier i dr., 2014). One upućuju na to da ruralna područja s različitim razvojnim preprekama zauzimaju značajan udio nacionalnog teritorija. Iako periferna ruralna područja sigurno nisu jedinstveno obilježje Hrvatske, Istočne i Jugoistočne Europe, njihova je posebnost u tome što ne obuhvaćaju samo udaljena područja ili područja s prirodnim nepogodnostima nego i takozvane unutarnje ruralne periferije (TA, 2011). Ovaj jedinstveni tip ruralnog prostora opisuje se kao područje sa slabom dostupnošću i nedostatkom razvijenijih urbanih centralnih naselja. Mnoge od njih karakterizira slaba lokalna ekonomija i nedostatak poslovnih prilika za mlade ljude. Negativni demografski procesi napreduju, napose emigracija i starenje stanovništva (TA, 2011). Kao posljedica toga zemljište se obično napušta, rezultirajući sekundarnom sukcesijom i aforestacijom.

Iako je ruralna depopulacija počela već u 19. stoljeću u krškim perifernim područjima, podrijetlo sustavnih problema u hrvatskim ruralnim područjima može se pratiti do socijalističkog razdoblja. Opća i agrarna politika postale su nepovoljne za privatna poljoprivredna gospodarstva, što je s dugoročnom depopulacijom, deagrarizacijom i osiromašivanjem rezultiralo njihovim socijalnim i ekonomskim slabljenjem. Domovinski rat i raspad socijalizma 1990ih uzrokovao je duboke socio-ekonomske i institucijske promjene (Lukić, 2012). Razdoblje tranzicije prema tržišnoj ekonomiji odlikovalo se ekonomskom krizom, depopulacijom, neuspješnom privatizacijom te narušavanjem sektorske strukture (Pejnović i Kordej-De Villa, 2015). Prethodno spomenuti uvjeti i procesi uvjetovali su napuštanje zemljišta i aforestaciju (Cvitanović i dr., 2016).

Promjene načina korištenja zemljišta i zemljišnog pokrova u postsocijalističkim državama Srednje i Istočne Europe bile su zanimljiva istraživačka tema posljednjih nekoliko godina. Nakon raspada socija-
Simulation Model of Land Cover Changes in a PostSocialist Peripheral Rural Area: PožegaSlavonia County, Croatia

Simulacijski model promjena zemljišnog pokrova u postsocijalističkom perifernom ruralnom području: Požeško-slavonska županija, Hrvatska 
LULC in post-socialist Central and Eastern European countries has been an interesting research topic during the last few years. After the collapse of the socialism in these countries, one of the main LULC trends was decrease in agricultural land use due to extensification, land abandonment and afforestation from one side, or suburbanisation on the other (Václavík and Rogan, 2009; Baumann et al., 2012; Alcantara et al., 2013; Griffiths et al., 2013). Similar studies have been conducted in the area of northern Croatia (Horvat, 2013; Cvitanović et al., 2016; Jogun et al., 2017), where similar trends and driving forces of LULC were detected, like in the previously mentioned papers. The methodology of those papers was based on analysis of historical LULC, while this study aims to extend them using predictive simulation models of LULC. Namely, simulation models are one of the most effective tools to study LULC, and they can additionally support land use planning and policy (Verburg et al., 2004). Many simulation models have been created during the two last decades, under initiatives like the Land Use and Land Cover Change Project of the International Geosphere-Biosphere Program (IGBP), and International Human Dimensions Program (IHDP) (Han et al., 2015). Most of the empirical studies employing LULC simulation models have dealt with dynamic areas that have undergone significant LULC such as deforestation, expansion of built-up areas and pressure on agricultural land due to urbanisation, population growth, and economic development in the last few decades (Pontius et al., 2008). This research will offer new insights on the performance of LULC simulation model in a postwar and post-socialist rural area, which can be applied to similar studies in the future.

The main goals of the study were to: (1) detect historical LULC and create a stochastic simulation model of LULC for one post-socialist peripheral rural region: a case study of Požega-Slavonia County from 1985 to 2027 ; (2) ascertain the relationship between complex rural typology and LULC in the case-study area; (3) assess suitability of artificial neural networks and cellular automata for modelling complex and nonlinear LULC; and (4) examine the potential of the LULC simulation model for the creation of development scenarios in the research area. lizma u tim državama, jedan od vodećih trendova u LULC-u bilo je smanjenje poljoprivrednog načina korištenja zemljišta zbog ekstenzifikacije, napuštanja zemljišta i aforestacije $s$ jedne strane ili suburbanizacije s druge strane (Václavík i Rogan, 2009; Baumann i dr., 2012; Alcantara i dr., 2013; Griffiths i dr., 2013). Slična su istraživanja provedena na području sjeverne Hrvatske (Horvat, 2013; Cvitanović i dr., 2016; Jogun i dr., 2017), gdje su utvrđeni slični trendovi i pokretači navedenih promjena kao u prethodnim istraživanja. Metodologija tih istraživanja temeljena je na analizi povijesnih promjena načina korištenja zemljišta i zemljišnog pokrova, dok ih ovo istraživanje nastoji proširiti uporabom predikcijskih simulacijskih modela. Naime, simulacijski modeli su jedan od najučinkovitijih alata za proučavanje LULC-a, a mogu i dodatno poduprijeti planiranje i politiku načina korištenja zemljišta (Verburg i dr., 2004). Mnoštvo simulacijskih modela stvoreno je tijekom posljednjih dvaju desetljeća, u inicijativama kao što su Land Use and Land Cover Change Project of the International Geosphere-Biosphere Program (IGBP) i International Human Dimensions Program (IHDP) (Han i dr., 2015). Većina empirijskih istraživanja temeljenih na simulacijskim modelima LULC-a bavila su se dinamičnim područjima koja su prošla značajne promjene kao što su urbanizacija, porast stanovništva te ekonomski razvoj u posljednjih nekoliko desetljeća (Pontius i dr., 2008). Ovo će istraživanje ponuditi nov uvid u izvedbu simulacijskog modela LULC-a u poslijeratnom i postsocijalističkom ruralnom području, koji se može primijeniti na slična istraživanja u budućnosti.

Glavni ciljevi ovog istraživanja bili su: (1) utvrditi povijesne promjene načina korištenja zemljišta i zemljišnog pokrova i stvoriti njihov stohastični simulacijski model za jednu postsocijalističku perifernu ruralnu regiju - studiju slučaja Požeško-slavonske županije od 1985. do 2027., (2) utvrditi povezanost između kompleksne ruralne tipologije i promjena načina korištenja zemljišta i zemljišnog pokrova u području studije slučaja, (3) utvrditi pogodnost umjetnih neuronskih mreža i ćelijskih automata za modeliranje kompleksnih i nelinearnih promjena načina korištenja zemljišta i zemljišnog pokrova i (4) ispitati potencijal njihova simulacijskog modela za izradu razvojnih scenarija u području istraživanja. 


\section{Research area and data}

Požega-Slavonia County, as a marginal rural area with diverse landscape features (lowlands vs mountains), and turbulent social conditions in the recent decades (fall of socialism, war, transition, and EU entrance) is a fine example for modelling land cover changes in similar areas of Central and Eastern Europe. It is located in the western part of the historical region of Slavonia, in eastern Croatia (Fig. 1). With a surface of $1823 \mathrm{~km}^{2}$ (CBS, 2015) and composite development index of $32.8 \%$ of the national average (Pejnović and Kordej-De Villa, 2015), it is one of the smallest and the most underdeveloped Croatian counties.

According to physical-geographic regionalisation, Požega-Slavonia County is part of the Pannonian

\section{Područje istraživanja i podatci}

Požeško-slavonska županija, kao marginalno ruralno područje s raznolikim reljefnim obilježjima (nizine nasuprot gorama) te turbulentnim socijalnim uvjetima posljednjih desetljeća (pad socijalizma, rat, tranzicija i pristup EU) dobar je primjer za modeliranje promjena zemljišnog pokrova u sličnim područjima Srednje i Istočne Europe. Smještena je na zapadnom dijelu povijesne regije Slavonije, u istočnoj Hrvatskoj (sl. 1). Površinom od 1823 km² (CBS, 2015) i kompozitnim razvojnim indeksom od 32,8 \% nacionalnog prosjeka (Pejnović i Kordej-De Villa, 2015) jedna je od najmanjih i najslabije razvijenih hrvatskih županija.

Prema fizičkogeografskoj regionalizaciji Požeško-slavonska županija pripada panonskoj mega-

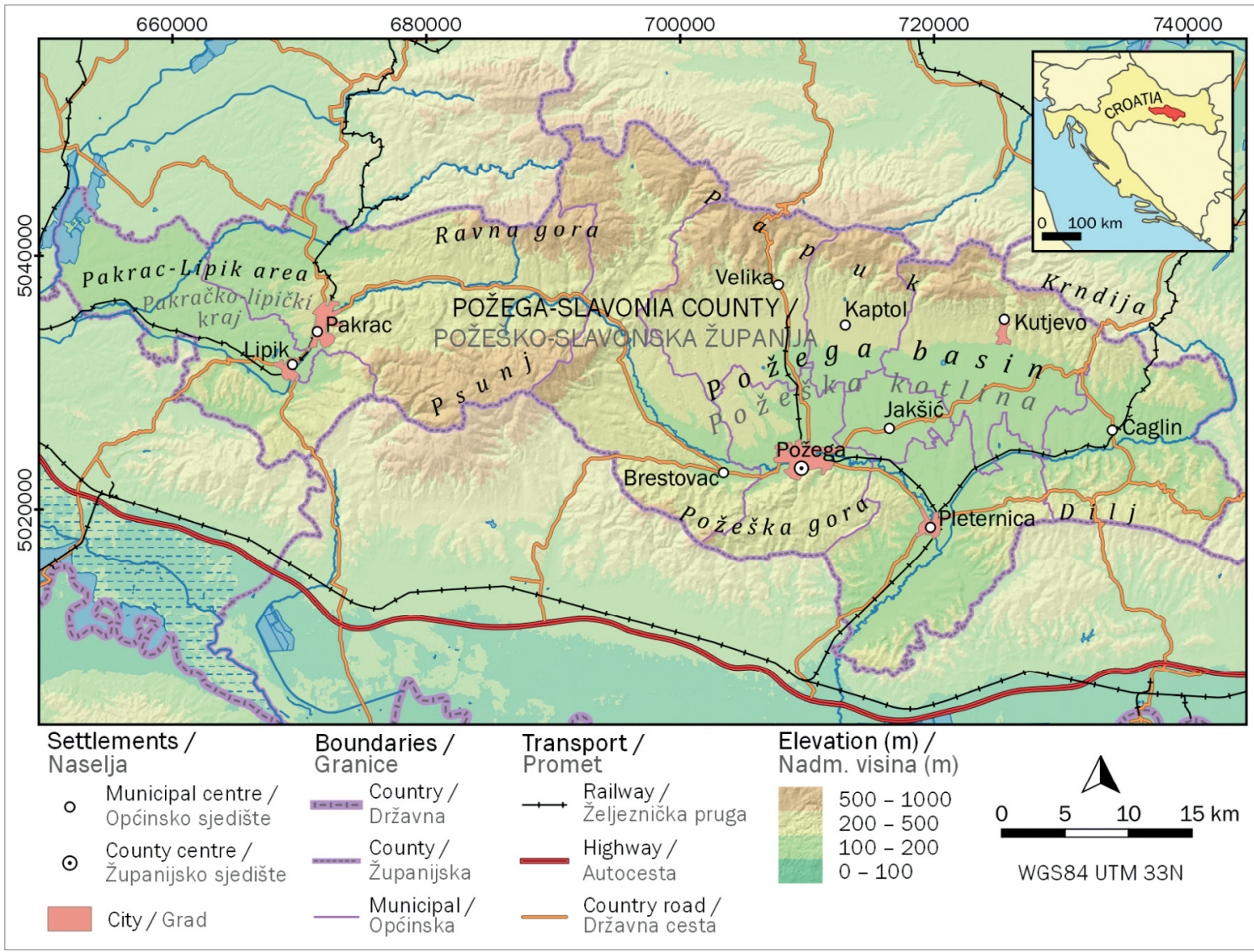

Fig. 1 Geographic location and features of Požega-Slavonia County, Croatia

SI. 1. Geografski položaj i obilježja Požeško-slavonske županije, Hrvatska

Source: according to EU-DEM; DARH, 2005

Izvor: prema EU-DEM; DARH, 2005 
Mega-Region, comprising two distinct units: the Požega Basin and the Pakrac-Lipik area (Bognar, 1999). The Požega Basin is surrounded by old mountains-Psunj, Papuk, Krndija, Požzeška Gora, and Dilj, which are covered with forests. In the central part of the basin real lowlands formed on quaternary deposits prevail, which are favourable for agriculture.

Požega-Slavonia County had 78,034 inhabitants in 2011, a respective general population density of 43 persons per square kilometre, which was less in comparison to 76 persons per square kilometre in Croatia as a whole. The number of settlements was large (277), as a consequence of traditional agrarian exploitation, and historical and natural conditions. Most of the settlements had populations less than 200, and 15 of them were unpopulated. The share of the urban population was $41.6 \%$, which was also below the Croatian average of $56 \%$, confirming the rural characteristics of the area (CBS, 2011). The Požega Basin has a very long history of human inhabitation, and until the second half of the $20^{\text {th }}$ century, it had been attractive for many immigrants. However, since the 1971 population census, this area has been losing population. The western part of the county was particularly struck by the Croatian War of Independence (1991-1995), the negative demographic and economic repercussions of which are still being felt today. Moreover, the negative trends of ageing and depopulation are set to undermine the demographic situation in the future (Njegač, 2012).

The temporal frame of the research was influenced by data availability, research methodology, and deep changes in the political and economic system that occurred in the research area. The base year for the test model was 1985, the launch year was 1999, and the target year for simulation was 2013. The final model had its base in 1999, the launch year was 2013, and the target year was 2027 .

The main data source was multispectral satellite images acquired by the Landsat mission, which were downloaded from the USGS EarthExplorer service. The criteria for their selection were: coverage of the same research area; availability of all bands (Level 1 Data Product); cloud-free scene; the same season (summer) for phenological consistency; and equal and sufficient periods between images. The earliest images were acquired by Landsat 5 TM on August regiji, obuhvaćajući dvije različite cjeline: Požešku kotlinu i pakračko-lipičko područje (Bognar, 1999). Požešku kotlinu omeđuju stare gore: Psunj, Papuk, Krndija, Požeška gora i Dilj-gora, koje su prekrivene šumama. U središnjem dijelu kotline prevladava pravi nizinski reljef formiran na kvartarnim naslagama, što je povoljno za poljoprivredu.

Požeško-slavonska županija imala je 2011. godine 78034 stanovnika, odnosno opću gustoću naseljenosti 43 stan. $/ \mathrm{km}^{2}$, što je bilo manje u odnosu na 76 stan. $/ \mathrm{km}^{2}$ u cijeloj Hrvatskoj. Broj naselja je velik (277), kao posljedica tradicionalnoga agrarnog iskorištavanja, povijesnih i prirodnih uvjeta. Većina je naselja imala manje od 200 stanovnika, a njih 15 nije imalo stanovnika. Udio gradskoga stanovništva bio je 41,6 \%, što je također bilo ispod hrvatskog prosjeka od $56 \%$, potvrđujući ruralna obilježja prostora (CBS, 2011). Požeška kotlina ima vrlo dugu povijest naseljenosti pa je sve do 18. stoljeća bila privlačna za doseljavanje. Međutim, nakon popisa stanovništva 1971. ovo područje gubi stanovništvo. Zapadni dijelovi županije osobito su bili pogođeni Domovinskim ratom (1991. - 1995.), čije se posljedice osjećaju i danas. K tomu, negativni trendovi starenja i depopulacije narušavat će demografsku sliku u budućnosti (Njegač, 2012).

Vremenski okvir istraživanja bio je uvjetovan dostupnošću podataka, metodologijom istraživanja i dubokim promjenama u političkom i gospodarskom sustavu koje su se dogodile u području istraživanja. Ishodišna godina za testni model bila je 1985., pokretačka godina bila je 1999., a ciljna godina simulacije bila je 2013. Konačni model imao je ishodište u 1999., a pokrenut je od 2013. s ciljem prema 2027. godini.

Glavni izvor podataka bile su multispektralne satelitske snimke prikupljene misijom Landsat, koje su preuzete sa servisa USGS EarthExplorer. Kriteriji za njihov izbor bili su: obuhvaćanje područja istraživanja, dostupnost svih kanala (Level 1 Data Product), scena bez oblaka, jednako godišnje doba (ljeto) radi fenološke usklađenosti te jednaka i dovoljno duga razdoblja između snimanja. Najranije snimke prikupio je Landsat 5 TM 10 . kolovoza 1985., drugi set je prikupio Landsat 7 ETM+ 
$10^{\text {th }}$, 1985; the second set was acquired by Landsat 7 ETM+ on August 9 $9^{\text {th }}, 1999$; and the most recent images were acquired by Landsat 8 OLI TIRS on August $7^{\text {th }}, 2013$. The images were downloaded in GeoTIFF format in $30 \mathrm{~m}$ spatial resolution, already georeferenced and georectified in the WGS 84 UTM $33 \mathrm{~N}$ coordinate system. Thermal and panchromatic bands were not used.

The digital terrain model, from which natural variables for the simulation model were derived, was retrieved from the European Environmental Agency. Its original spatial resolution was $25 \mathrm{~m}$ and its projection ETRS89 LAEA, so it was resampled to $30 \mathrm{~m}$ by the nearest neighbour method and re-projected to WGS 84 UTM 33N. The data on areas suspected to be mined were retrieved from the Croatian Mine Action Centre. Administrative boundaries were obtained from the Digital Atlas of the Republic of Croatia. Ancillary spatial data were: the Croatian Base Map in the scale of 1:5000 in the period of 1980-1990, the topographic map in the scale of 1:25,000 in the period of 2001-2003, and the Digital orthophoto map in the scale of 1:5000 from 2011 via the State Geodetic Administration Geoportal Web Mapping Service; aerial photogrammetric images from 2001 were bought from the State Geodetic Administration; and high-resolution satellite images were acquired by the SPOT 6 in 2013 via the Open Layers service. Statistical data were obtained from the 2001 Census and the 2011 Census of the Croatian Bureau of Statistics.

\section{Methods}

\section{Land cover classification}

The classification scheme consisted of five classes: water; built-up; crops and soil; grass and shrubs; and forest. The scenes were classified using the supervised method in Semi-Automatic Classification Plugin for QGIS, using the maximum likelihood algorithm. Training samples for classes were chosen on the basis of "true colour" (red, green, and blue bands) and "false colour" RGB composites (bands from the infrared and visible parts of the spectrum), and with more accurate ancillary data. Regarding the fact that the class of built-up land usually gets the most mixed up with
9. kolovoza 1999. godine, a najnovije snimke prikupio je Landsat 8 OLI TIRS 7. kolovoza 2013. godine. Snimke su preuzete u GeoTIFF formatu s prostornom rezolucijom 30 metara, unaprijed georeferencirane i georektificirane u koordinatnom sustavu WGS 84 UTM. Termalni i pankromatski kanali nisu bili upotrijebljeni.

Digitalni model reljefa koji je služio u simulacijskom modelu za izvođenje prostornih čimbenika preuzet je s internetske stranice Europske agencije za okoliš. Njegova izvorna prostorna rezolucija bila je $25 \mathrm{~m}$, a projekcija ETRS89 LAEA, zbog čega je preuzorkovan na 30 m metodom najbližega susjeda u projekciju WGS 84 UTM 33N. Podatci o minski sumnjivim područjima dobiveni su od Hrvatskog centra za razminiranje, a administrativne granice potječu iz Digitalnog atlasa RH. Dodatni prostorni podatci služili su za kontrolu klasifikacije: hrvatska osnovna karta u mjerilu $1: 5000$ iz 1980. - 1990. godine, topografska karta u mjerilu $1: 25.000$ iz 2001. - 2003. godine i digitalna ortofoto karta u mjerilu 1 : $5000 \mathrm{iz} \mathrm{2011.} \mathrm{go-}$ dine preko WMS-a Geoportala Državne geodetske uprave, aerofotogrametrijske snimke iz 2001. godine kupljene od Državne geodetske uprave i satelitske snimke visoke rezolucije iz 2013. godine snimljene satelitom SPOT 6 preko servisa Open Layers. Statistički podatci preuzeti su iz Popisa stanovništva 2001. i 2011. godine Državnog zavoda za statistiku.

\section{Meode}

\section{Klasifikacija zemljišnog pokrova}

Klasifikacijska shema sastojala se od pet klasa: voda; izgrađeno; usjevi i tlo; trava i šikara; šuma. Scene su klasificirane nadziranom metodom u dodatku Semi-Automatic Classification Plugin za QGIS, uporabom algoritma maximum likelihood. Uzorci za treniranje izabrani su na temelju tzv. true colour (crveni, zeleni i plavi kanal) i false colour RGB kompozita (kanali iz infracrvenog dijela spektra) te iz točnijih dodatnih podataka. S obzirom na to da se klasa izgrađenog zemljišta obično miješa s drugim klasama jer obuhvaća mozaik
Simulation Model of Land Cover Changes in a PostSocialist Peripheral Rural Area: PožegaSlavonia County, Croatia

Simulacijski model promjena zemljišnog pokrova u postsocijalističkom perifernom ruralnom području: Požeško-slavonska županija, Hrvatska 
the other classes because it incorporates a mosaic of buildings, vegetation, and soil, the classification was conducted separately for built-up and for other land, following recommendations from Horvat (2013). In this procedure, the built-up land was manually delineated from ancillary data. After finishing the entire classification, modal filtering with a $3 \times 3$-pixel neighbourhood size was carried out to reduce noise.

Reference samples for the classification accuracy assessment were determined independently from the classification results and training samples, by the same method used for the training samples. The quantitative measures of accuracy were omission, commission, and overall agreement, instead of a deficient Kappa coefficient (Pontius and Millones, 2011).

\section{Simulation of land cover changes}

The simulation model of LULC in this research was conducted in MOLUSCE (Modules for Land Use Change Evaluation), which is an open-source plugin for QGIS (MOLUSCE, 2018). The plugin implements the following functionalities: takes input data of land cover categories and explanatory variables; trains LULC model using input data and well-known algorithms; predicts future LULC based on the training input; and performs validation of results based on reference data from the past (GIS-Lab, 2018).

For modelling LULC transition potential, four algorithms can be used, i.e. artificial neural network (ANN), logistic regression, weight of evidence, and multi-criteria evaluation (MOLUSCE, 2018). We selected results from ANN multi-layer perceptron because they had the highest accuracy compared to the other algorithms.

ANNs are a form of machine learning that is used increasingly because of advances in computing performance and the increased availability of flexible software (Pijanowski et al., 2002). It is one of the most successful systems in remote sensing used for land cover classification (Gašparović and Jogun, 2018), and modelling LULC. It is very good at coping with incorrect and poor data, and capturing complex non-linear features in modelling processes (Li and Yeh, 2002). ANNs consist zgrada, vegetacije i tla, klasifikacija je provedena odvojeno za izgrađeno i ostalo zemljište, prema preporuci u Horvat (2013). U tom je postupku ručno izdvojeno izgrađeno zemljište iz dodatnih podataka. Nakon konačnog klasificiranja načinjeno je modalno filtriranje s prozorom $3 \times 3$ ćelije kako bi se smanjio šum.

Referentni uzorci za testiranje točnosti klasifikacije određeni su neovisno o rezultatima klasifikacije i uzorcima za treniranje, jednakom metodom kao uzorci za treniranje. Kvantitativne mjere točnosti bile su pogreške isključenja i uključenja te ukupno slaganje, umjesto manjkavog kapa koeficijenta (Pontius i Millones, 2011).

\section{Simulacija promiena zemljišnoga pokrova}

Simulacijski model promjena načina korištenja zemljišta i zemljišnog pokrova u ovom je istraživanju realiziran u MOLUSCE-u (Modules for Land Use Change Evaluation), koji je dodatak otvorenog koda za QGIS (MOLUSCE, 2018). Dodatak posjeduje sljedeće funkcionalnosti: uzima ulazne podatke kategorija zemljišnog pokrova i eksplanatornih varijabla, trenira model uporabom ulaznih podataka i poznatih algoritama, predviđa buduće promjene načina korištenja zemljišta i zemljišnog pokrova na temelju treninga i izvodi validaciju rezultata pomoću referentnih podataka iz prošlosti (GIS-Lab, 2018).

$\mathrm{Za}$ modeliranje tranzicijskog potencijala LULC-a mogu se upotrijebiti četiri algoritma: umjetne neuronske mreže (ANN), logistička regresija, težina dokaza i multikriterijsko vrednovanje (MOLUSCE, 2018). Ovdje su izabrani rezultati algoritma $A N N$ multi-layer perceptron jer su imali najvišu točnost $\mathrm{u}$ usporedbi s drugim algoritmima.

ANN je oblik strojnog učenja koji se sve više rabi zbog napretka računala i povećane dostupnosti fleksibilnih softvera (Pijanowski i dr., 2002). ANN je jedan od najuspješnijih sustava u daljinskim istraživanjima koji se primjenjuje za klasifikaciju zemljišnog pokrova (Gašparović i Jogun, 2018) i modeliranje promjena načina korištenja zemljišta i zemljišnog pokrova. Vrlo se dobro nosi s netočnim i nepotpunim podatcima te kompleksnim nelinearnim obilježjima 
of layers and neurons that imitate the structure of the human brain and its ability to sort patterns and learn from trials and errors, thus observing relationships in data (Pijanowski et al., 2002). The most widely used form of ANN is the multi-layer perceptron (MLP), described by Rumelhart et al. (1986).

The MOLUSCE plugin uses classical realisation of an MLP ANN with backpropagation. It performs initial preprocessing of the input data (dummy coding of categorical variables into a set of independent variables, and normalisation of factor variables), sampling, and training (GIS-Lab, 2018). For each model, there were 1000 randomly selected samples based on 1-size Moore neighbourhood $(3 \times 3$ window size $)$.

In the backpropagation algorithm, momentum is used for the learning procedure, and weights corrections are calculated as:

$$
w(n+1)=r * d w(n)+m * d w(n-1)
$$

where $w$ is a vector of neuron weights, $d w$ is a vector of weights changes, $n$ is an iteration number, $r$ is learning rate, $m$ is momentum. Training set is divided into learning set ( $80 \%$ of samples) and validation set (20\% of samples). Learning is stochastic, where a random sample is selected from the learning set, and the weights of the network are updated during forward/backward propagation. A fitting error for a sample is calculated as:

$$
E=\frac{t_{i}-o_{i}}{d}
$$

where $E$ is a sample error, $t_{i}$ is the target value of a output neuron for given sample, $o_{i}$ is the real output value of the neuron, $d$ is the count of output neurons (GIS-Lab, 2018). Models in this research were trained with learning rate and momentum parameters set to 0.001 in order to stabilise the learning graph. A number of iterations was set to 200 in order to avoid problems with model over-fitting.

Simulation step is performed with Cellular automata (CA), which is the most well-known LULC concept. The main idea of CA is that LULC can be explained by the current state of a "cell" and its u procesu modeliranja (Li i Yeh, 2002). ANN se sastoji od slojeva i neurona koji oponašaju strukturu ljudskog mozga i njegovu sposobnost sortiranja uzoraka i učenja iz pokušaja i pogrešaka uočavajući tako veze u podatcima (Li i Yeh, 2002). Najrašireniji oblik ANN-a u praksi je multi-layer perceptron (MLP), koji su opisali Rumelhart i dr. (1986).

Dodatak MOLUSCE upotrebljava klasičnu realizaciju MLP ANN-a s povratnim prenošenjem. On izvodi početnu predobradu ulaznih podataka (naivno kodiranje kategorijskih varijabli u skup nezavisnih varijabli te normalizacija faktorskih varijabli), uzorkovanje i treniranje (GIS-Lab, 2018). Za svaki je model nasumično izabrano po 1000 uzoraka temeljenih na Mooreovu susjedstvu veličine 1 (veličina prozora $3 \times 3$ ).

U algoritmu povratnog prenošenja momentum se rabi za proces učenja, a popravke težina računaju se kao:

$w(n+1)=r * d w(n)+m * d w(n-1)$

gdje je $w$ vektor težina neurona, $d w$ je vektor težina promjena, $n$ je broj iteracija, $r$ je stopa učenja, $m$ je momentum. Skup za treniranje podijeljen je na skup za učenje (80 \% uzoraka) i skup za validaciju (20 \% uzoraka). Učenje je stohastično, pri čemu se bira slučajni uzorak iz skupa za učenje, a težine mreže ažuriraju se tijekom unaprijednog/povratnog prenošenja. Pogreška kalibracije za uzorak računa se kao:

$$
E=\frac{t_{i}-o_{i}}{d}
$$

gdje je $E$ pogreška uzorka, $t_{i}$ je ciljna vrijednost izlaznog neurona za dani uzorak, $o_{i}$ je stvarna izlazna vrijednost neurona, $d$ je broj izlaznih neurona (GIS-Lab, 2018). Modeli u ovom istraživanju trenirani su sa stopom učenja i momentumom postavljenim na 0,001 kako bi se stabilizirao graf učenja. Broj iteracija postavljen je na 200 kako bi se izbjegao problem s pretjeranom kalibracijom modela.

Korak simulacije izvodi se ćelijskim automatima (CA), koji su najpoznatiji koncept LULC-a. Osnovna je ideja ćelijskih automata da se promjene načina korištenja zemljišta i zemljišnog pokrova mogu objasni-
Simulation Model of Land Cover Changes in a PostSocialist Peripheral Rural Area: PožegaSlavonia County, Croatia

Simulacijski model promjena zemljišnog pokrova u postsocijalističkom perifernom ruralnom području:

Požeško-slavonska županija, Hrvatska 
changes in the neighbourhood (van Schrojenstein Lantman et al., 2011).

The CA implemented in MOLUSCE takes as input the next data: initial state raster (current land cover categories); factor rasters (explanatory variables); and model (transition potentials that are the output of an algorithm, e.g. an ANN). The simulator takes transition probabilities from the transition matrix, calls a model, and feeds it with initial state and factor rasters. The model calculates transition potentials of every transition class, and the simulator constructs a raster of the most probable transitions. For every transition class in the raster of the most probable transitions, the simulator searches a needed count of pixels with the greatest certainty and changes the category of the pixels (GIS-Lab, 2018). Simulations in this research were performed in two iterations, meaning that the described procedure was repeated with the first simulated map as the initial state map for the second iteration. Because the model integrates $\mathrm{CA}$ and $\mathrm{ANN}$, it will be referenced as $\mathrm{CA}-\mathrm{ANN}$ in the rest of the paper.

Calibration and validation are essential elements of the simulation model. A clear distinction between these terms was made in Pontius et al. (2004). The simplest method for validation is a null model. The simulation model is calibrated with data from time $t_{1}$, and validation is based on the comparison of the simulated map for $t_{2}$ with the observed map in $t_{2}$. The null model assumes persistence, i.e. no change between $t_{1}$ and $t_{2}$. If the null model (map from $t_{1}$ ) is more similar to the observed map from $t_{2}$ than the simulated map, it means that the simulation is not satisfactory. We conducted a three-way map comparison, which considered the agreement between two pairs of three maps: the reference map of $t_{1}$; the reference map of $t_{2}$; and the simulated map for $t_{2}$. This three-map comparison allowed us to distinguish the pixels that were correct due to persistence, versus the pixels that were correct due to change. Mathematical expressions for measurements defined by a combination of information of quantity and location can be found in previous papers, i.e. overall quantity disagreement and agreement (Pontius and Millones, 2011), overall shift and exchange (Pontius and Santacruz, 2014), and figure of merit for prediction (Pontius et al., 2008). ti trenutnim stanjem „ćelije” i promjenama u njezinu susjedstvu (van Schrojenstein Lantman i dr., 2011).

Ćelijski automati ugrađeni u MOLUSCE prihvaćaju kao ulaz sljedeće podatke: raster početnog stanja (trenutne kategorije zemljišnog pokrova), raster faktora (eksplanatorne varijable) i model (tranzicijski potencijal koji je izlaz algoritma, npr. ANN). Simulator uzima tranzicijske vjerojatnosti iz tranzicijske matrice, poziva model te mu prosljeđuje rastere početnog stanja i faktora. Model računa tranzicijski potencijal za svaku klasu promjena, a simulator stvara raster najvjerojatnijih promjena. Za svaku klasu promjena u rasteru najvjerojatnijih promjena simulator traži potreban broj ćelija s najvećom sigurnošću i mijenja kategorije ćelija (GIS-Lab, 2018). Simulacije $\mathrm{u}$ ovom istraživanju provedene su u dvije iteracije, što znači da je opisana procedura ponovljena s prvom simuliranom kartom kao kartom početnog stanja za drugu iteraciju. Budući da model integrira CA i ANN, u nastavku rada navodit će se kao CA-ANN.

Kalibracija i validacija bitni su elementi simulacijskog modela. Jasna distinkcija između ovih pojmova načinjena je u Pontius i dr. (2004). Najjednostavnija metoda validacije je tzv. nul-model. Simulacijski model kalibrira se s podatcima iz vremena $t_{1}$, a validacija se temelji na usporedbi simulirane karte za $t_{2} \mathrm{~s}$ opaženom kartom u $t_{2}$. Nul-model pretpostavlja perzistenciju, tj. da nije došlo do promjena između $t_{1}$ i $t_{2}$. Ako je nul-model (karta iz $t_{1}$ ) sličniji opaženoj karti iz $t_{2}$ nego simulirana karta, to znači da simulacija nije zadovoljavajuća. Ovdje je provedena trostruka usporedba karata koja podrazumijeva slaganje između parova triju karata: referentne karte za $t_{1}$, referentne karte za $t_{2}$ i simulirane karte za $t_{2}$. Ta trostruka usporedba karata omogućila je izdvajanje ćelija koje su bile točne zbog perzistencije nasuprot ćelijama koje su bile točne zbog promjena. Matematički izrazi za mjere definirane kombinacijom informacija o kvantiteti i lokaciji mogu se pronaći u prethodnim istraživanjima, tj. ukupno kvantitativno neslaganje i slaganje (Pontius i Millones, 2011), ukupni pomak i razmjena (Pontius i Santacruz, 2014), i faktor kakvoće projekcije (Pontius i dr., 2008). 


\section{Land cover classification}

Most of the land in Požega-Slavonia County in 1985, 1999, and 2013 was covered with forests, especially in mountainous areas. Crops and soil prevailed in lowlands, while grass and shrubs dominated in the zones in between. Built-up and water

\section{Klasifikacija zemlijšnog pokrova}

Većina je zemljišta u Požeško-slavonskoj županiji 1985., 1999. i 2013. godine bila pokrivena šumama, osobito u gorskim predjelima. Usjevi i tlo prevladavali su u nizinama, dok su trava i šikara dominirali u srednjim visinskim zonama. Izgrađene i

Simulation Model of Land Cover

Changes in a PostSocialist Peripheral

Rural Area: Požega-

Slavonia County, Croatia

Simulacijski model promjena zemljišnog pokrova u postsocijalističkom perifernom ruralnom području:

Požeško-slavonska županija, Hrvatska

Fig. 2 Land cover classification in Požega-Slavonia County in 1985,1999 , and 2013

SI. 2. Klasifikacija zemlijšnog pokrova u Požeško-slavonskoj Županiji 1985., 1999. i 2013.

Source: derived from the EarthExplorer data; DARH, 2005

Izvor: obrada podataka sa stranice EarthExplorer; DARH,

2005.

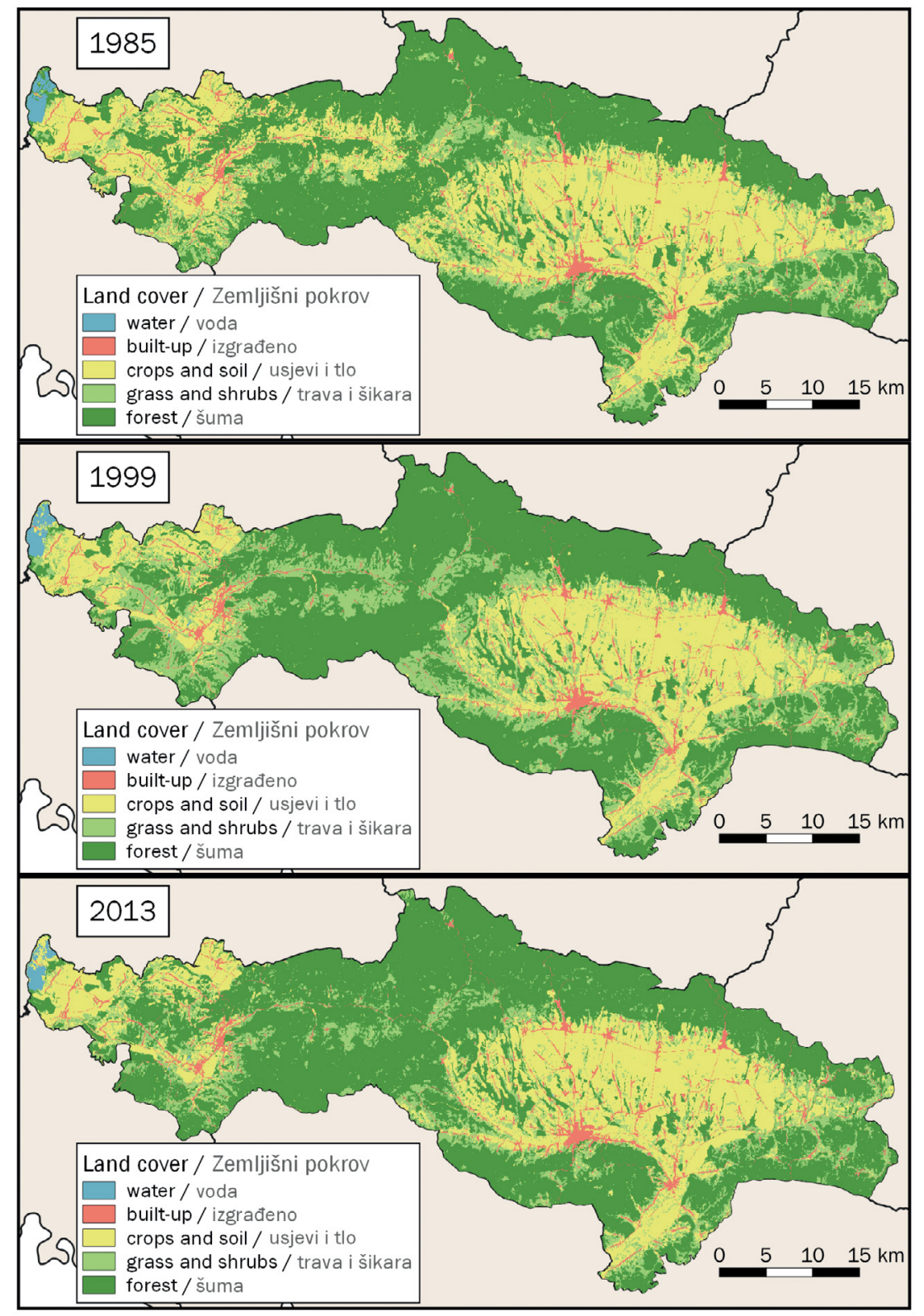


HRVATSKI

GEOGRAFSKI

GLASNIK

81/1,31-59 (2019.)

Tab. 1 Land cover classification accuracies (in \%)

Tab. 1. Točnost klasifikacija zemljišnog pokrova (u \%)

\begin{tabular}{|l|c|c|c|c|c|c|}
\hline & \multicolumn{2}{|c|}{1985} & \multicolumn{2}{c|}{1999} & \multicolumn{2}{c|}{2013} \\
\hline & O* & C** & O & C & O & C \\
\hline Water / Voda & 0.00 & 0.00 & 0.00 & 0.00 & 1.87 & 0.00 \\
\hline Built-up / Izgrađeno & 0.00 & 0.00 & 0.61 & 0.12 & 0.00 & 0.97 \\
\hline Crops and soil / Usjevi i tlo & 0.15 & 2.90 & 6.91 & 4.10 & 1.13 & 0.51 \\
\hline Grass and shrubs / Trava i šikara & 7.65 & 1.12 & 12.39 & 11.84 & 11.85 & 9.76 \\
\hline Forest / Šuma & 0.28 & 0.29 & 1.33 & 3.20 & 2.01 & 2.83 \\
\hline Overall agreement / Ukupno slaganje & \multicolumn{2}{|c|}{98.69} & \multicolumn{3}{|c|}{94.95} & \multicolumn{3}{c|}{96.89} \\
\hline
\end{tabular}

* Error of omission / Pogreška iskjjučenja

** Error of commission / Pogreška uključenja

Source: derived from the EarthExplorer data

Izvor: obrada podataka sa stranice EarthExplorer

areas had the smallest share-less than $5 \%$ of the total area (Fig. 2).

Considering that the most problematic class (built-up) was delineated manually, the overall classification accuracy was high: 98.7\%; 95\%; and 96.9\%—for 1985, 1999, and 2013 respectively. The largest errors of omission and commission were in the class of grass and shrubs (Tab. 1).

The largest change from 1985 to 1999 was a decrease in crops and soil, and an increase in grass and shrubs, and forest. From 1999 to 2013, the most signif- vodene površine imale su najmanji udio - manje od $5 \%$ ukupne površine (sl. 2).

S obzirom na to da je najproblematičnija klasa (izgrađeno) izdvojena ručno, ukupna točnost klasifikacije bila je visoka: 98,7 \%; $95 \%$ i 96,9 \% - za 1985., 1999., i 2013. godinu. Najveće pogreške isključenja i uključenja bile su u klasi trava $i$ šikara (tab. 1).

Najveća promjena od 1985. do 1999. bilo je smanjenje usjeva i tla te porast trave i grmlja te šuma. Od 1999. do 2013. najznačajnija je promjena bilo

Tab. 2 Net changes of land cover in Požega-Slavonia County 1985-1999-2013

Tab. 2. Neto promjene zemljišnog pokrova u Požeško-slavonskoj županiji 1985. - 1999. - 2013.

\begin{tabular}{|l|c|c|c|c|c|c|c|c|c|c|}
\hline & \multicolumn{2}{|c|}{1985} & \multicolumn{2}{c|}{1999} & \multicolumn{2}{c|}{$\mathbf{2 0 1 3}$} & \multicolumn{2}{c|}{$\mathbf{1 9 8 5 - 1 9 9 9}$} & \multicolumn{2}{c|}{$\mathbf{1 9 9 9 - 2 0 1 3}$} \\
\hline & ha & $\%$ & ha & $\%$ & ha & $\%$ & ha & $\%$ & ha & $\%$ \\
\hline $\begin{array}{l}\text { Water / } \\
\text { Voda }\end{array}$ & 813 & 0.4 & 898 & 0.5 & 678 & 0.4 & 85 & 0.0 & -220 & -0.1 \\
\hline $\begin{array}{l}\text { Built-up / } \\
\text { Izgrađeno }\end{array}$ & 6926 & 3.8 & 7242 & 4.0 & 7196 & 3.9 & 316 & 0.2 & -47 & 0.0 \\
\hline $\begin{array}{l}\text { Crops and soil / } \\
\text { Usjevi i tlo }\end{array}$ & 63727 & 35.0 & 47546 & 26.1 & 47933 & 26.3 & -16181 & -8.9 & 387 & 0.2 \\
\hline $\begin{array}{l}\text { Grass and shrubs / } \\
\text { Trava i šikara }\end{array}$ & 25020 & 13.7 & 37008 & 20.3 & 25442 & 14.0 & 11989 & 6.6 & -11566 & -6.3 \\
\hline $\begin{array}{l}\text { Forest / } \\
\text { Suma }\end{array}$ & 85747 & 47.1 & 89538 & 49.1 & 100984 & 55.4 & 3791 & 2.1 & 11446 & 6.3 \\
\hline
\end{tabular}

Source: derived from the EarthExplorer data

Izvor: obrada podataka sa stranice EarthExplorer 
icant change was a reduction in grass and shrubs, and an increase in forest cover. The changes in built-up and water, the smallest classes, were not significant (Tab.2).

The most compact areas of change from cultivated land to grass and shrubs were in the mountainous parts of Psunj and Pakračka gora, and the Pakrac-Lipik area, which were the hardest struck by smanjenje trave i šikare te porast šumskog pokrova. Promjene u najmanjim klasama (izgrađeno, voda) nisu bile značajne (tab. 2).

Najkompaktnija područja zarastanja obrađenih površina u travu i šikaru bila su u gorskim dijelovima Psunja i Pakračke gore te pakračko-lipičkog kraja, koji su bili najteže pogođeni Do-

Simulation Model of Land Cover

Changes in a PostSocialist Peripheral

Rural Area: Požega-

Slavonia County, Croatia

Simulacijski model promjena zemljišnog pokrova u postsocijalističkom perifernom ruralnom području: Požeško-slavonska županija, Hrvatska

Fig. 3 Land cover changes in Požega-Slavonia County in the period of 1985-1999

SI. 3. Promiene zemljišnog pokrova u Požeško-slavonskoj županiiji 1985. - 1999.

Legend:

0 - no change, 1 - water, 2 - built-up, 3 - crops and soil, 4 - grass and shrubs, 5 - forest

Legenda:

0 - bez promjene, 1 - voda,

2- izgrađeno, 3 - usjevi i tlo,

4 - trava i šikara, 5 - šuma

Source: derived from the EarthExplorer data; DARH, 2005.

Izvor: obrada podałaka sa stranice EarthExplorer; DARH,

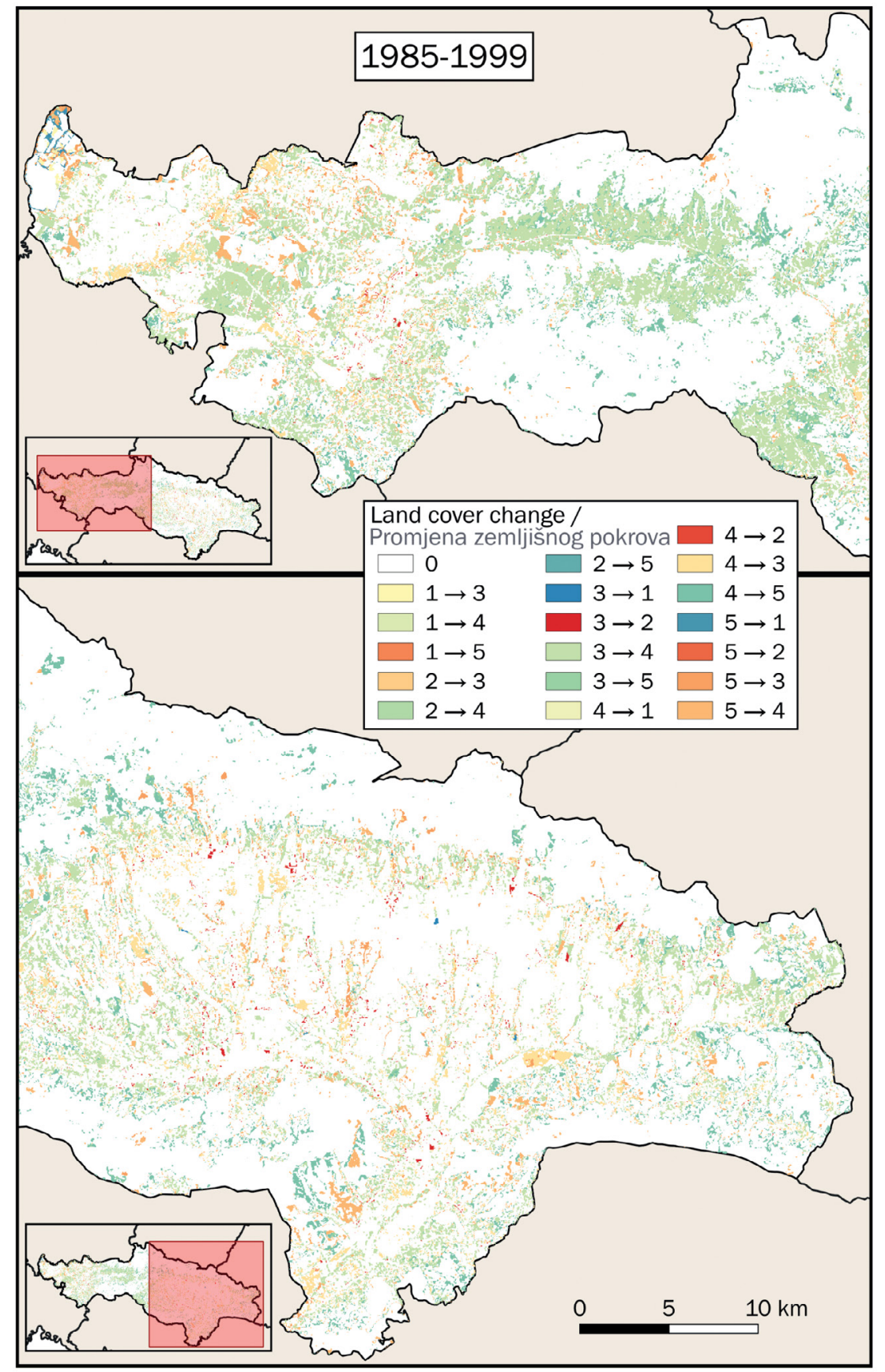


HRVATSKI

GEOGRAFSKI

GLASNIK

81/1,31-59 (2019.) both the Croatian War of Independence and subsequent depopulation. Most of the extensive changes were grouped in the elevation zone of 200-400 m, while the highest mountainous parts (covered with forest, unpopulated) and the lowest parts of lowlands (agricultural areas, demographically relatively stable) were less prone to change (Fig. 3; Fig. 4). movinskim ratom i depopulacijom. Većina ekstenzivnih promjena bila je grupirana u visinskoj zoni $200-400 \mathrm{~m}$, dok su najviši dijelovi gorja (pokriveni šumom, bez stanovništva) i najniži dijelovi nizina (poljoprivredna područja, demografski relativno stabilna) bili izloženi manjim promjenama (sl. 3; sl. 4).

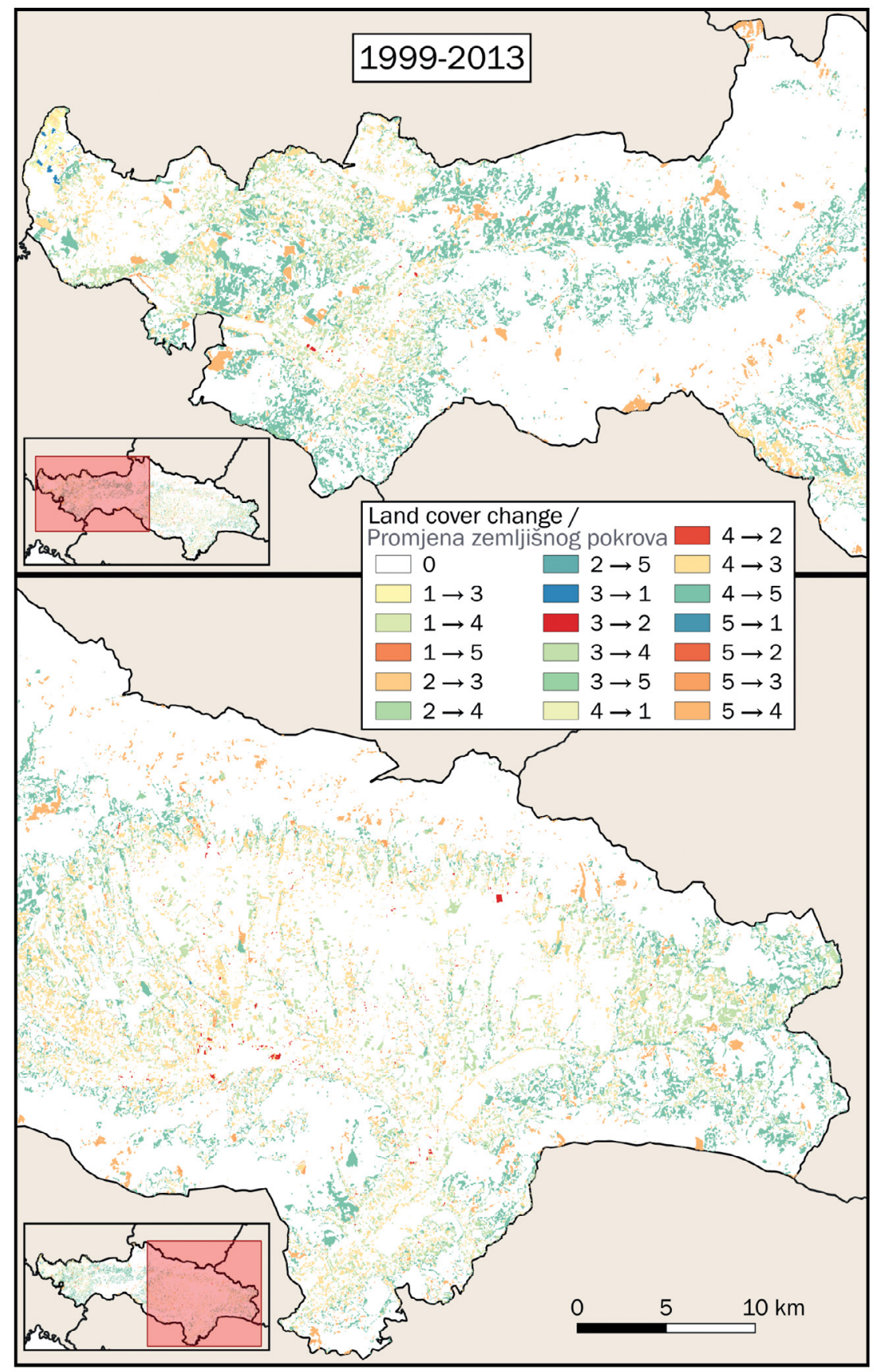

Fig. 4 Land cover changes in Požega-Slavonia County in the period of 1999-2013

SI. 4. Promjene zemljišnog pokrova u Požeško-slavonskoj županiij 1999. - 2013.

Legend:

0 -no change, 1 -water

2 - built-up, 3 - crops and soil,

4 - grass and shrubs, 5 - forest

Legenda:

0 - bez promjene, 1 -voda 2 - izgrađeno, 3 - usjevi i tlo 4 - trava i šikara, 5 - šuma

Source: derived from the EarthExplorer data; DARH, 2005.

Izvor: obrada podataka sa stranice EarthExplorer; DARH 2005. 
Tab. 3 Changes in the share of forest cover in the period of 1999-2013, by types of settlements in Požega-Slavonia County Tab. 3. Udio šumskog pokrova i njegove promjene 1999. - 2013. po tipovima naselja u Požeško-slavonskoj županiji

\begin{tabular}{|l|c|c|c|}
\hline \multirow{2}{*}{$\begin{array}{l}\text { Types of settlements (Lukić, 2012) / } \\
\text { Tipovi naselja (Lukić, 2012) }\end{array}$} & \multicolumn{3}{|c|}{ Forest cover (\%) / } \\
\cline { 2 - 4 } & $\mathbf{1 9 9 9}$ & $\mathbf{2 0 1 3}$ & $\mathbf{\Delta ~ 1 9 9 9 - 2 0 1 3}$ \\
\hline $\begin{array}{l}\text { Economically diversified settlements / } \\
\text { Ekonomski diversificirana naselja }\end{array}$ & 78.01 & 78.27 & 0.27 \\
\hline $\begin{array}{l}\text { Dynamic, structurally-stronger settlements / } \\
\text { Dinamična, strukturno jača naselja }\end{array}$ & 45.63 & 47.09 & 1.45 \\
\hline $\begin{array}{l}\text { Other rural settlements (mostly small) / } \\
\text { Ostala izvangradska naselja }\end{array}$ & 69.95 & 80.20 & 10.25 \\
\hline $\begin{array}{l}\text { Settlements in the rural periphery / } \\
\text { Naselja ruralne periferije }\end{array}$ & 62.42 & 74.05 & 11.63 \\
\hline $\begin{array}{l}\text { Settlements with agricultural extensification / } \\
\text { Naselja poljoprivredne ekstenzifikacije }\end{array}$ & 41.67 & 49.14 & 7.47 \\
\hline $\begin{array}{l}\text { Market-oriented agricultural settlements / } \\
\text { Tržišno orijentirana poljoprivredna naselja }\end{array}$ & 34.97 & 39.72 & 4.75 \\
\hline $\begin{array}{l}\text { Unpopulated settlements in 2001/ } \\
\text { Naselja bez stanovnika 2001. }\end{array}$ & 86.39 & 91.11 & 4.72 \\
\hline $\begin{array}{l}\text { Urban settlements / } \\
\text { Gradska naselja }\end{array}$ & 34.40 & 35.39 & 0.99 \\
\hline
\end{tabular}

Source: derived from the EarthExplorer data

Izvor: obrada podataka sa stranice EarthExplorer

Trends of extensification and afforestation in Požega-Slavonia County were correlated with development types of particular settlements, which were typed using 59 variables (Lukić, 2012). The share of forest cover and its growth in the period of 19992013 were the highest in the least-developed areas (settlements in the rural periphery, other settlements, unpopulated settlements, settlements with agricultural extensification) (Tab. 3), which were the most influenced by restrictive natural and social factors.

\section{Land cover change variables}

The initial variables for LULC in the test simulation model 1985-1999-2013 were: elevation; slope; aspect; distance from rivers; distance from lakes and reservoirs; distance from precedent LULC; general population density by settlements in 2001; population growth index 2001/1991 by settlements; juvenile index in 2001 (population
Trendovi ekstenzifikacije i aforestacije u Požeško-slavonskoj županiji bili su povezani s razvojnim obilježjima pojedinih naselja, koja su tipizirana prema 59 varijabli (Lukić, 2012). Udio šumskog pokrova i njegov porast 1999. - 2013. godine bili su najviši u najslabije razvijenim područjima (naselja ruralne periferije, ostala naselja, naselja bez stanovnika, naselja poljoprivredne ekstenzifikacije) (tab. 3), koja su bila najviše pod utjecajem ograničavajućih prirodnih i društvenih faktora.

\section{Varijable promjena zemljišnog pokrova}

Početne varijable za LULC u testnom simulacijskom modelu 1985. - 1999. - 2013. godine bile su: nadmorska visina, nagib padina, orijentacija padina, udaljenost od rijeka, udaljenost od voda stajaćica, udaljenost od proteklih promjena zemljišnog pokrova, prosječna gustoća stanovništva po naseljima 2001., indeks ukupnog kretanja stanovništva 
GEOGRAFSKI

GLASNIK

81/1,31-59 (2019.) 0-14/population $65+$ ) by settlements; distance from built-up settlements; distance from settlements with population greater than 1000; distance from traffic network; and distance from areas suspected to be mined.

Because of multicollinearity or low explanatory power, the following were excluded from the initial variables: aspect; population growth index; distance from traffic network; and distance from built-up settlements.

\section{Test simulation of land cover changes (1999-2013)}

Transition probabilities were computed with the Markov chain analysis for the period of 1985-1999 (Tab. 4).

Different combinations of parameters and variables produced dozens of simulated land cover maps for 2013. Because of the stochastic nature of the model, three maps produced with optimal parameters were combined by a modal function into one final land cover map for 2013 (Fig. 5).

The overall agreement of the three maps varied from $82.2 \%$ to $82.87 \%$. Combining the three maps
2001./1991. po naseljima, indeks mladosti stanovništva (< $15 / \geq 65$ god.) 2001. po naseljima, udaljenost od izgrađenih dijelova naselja, udaljenost od naselja većih od 1000 stanovnika, udaljenost od prometnica i udaljenost od minskih područja.

Zbog multikolinearnosti ili slabe eksplanatorne moći od početnih varijabla isključene su: orijentacija padina, indeks kretanja stanovništva, udaljenost od prometnica i izgrađenih naselja.

\section{Testna simulacija promjena zemljišnog pokrova (1999. - 2013.)}

Tranzicijske vjerojatnosti izračunane su metodom Markovljevib lanaca za razdoblje 1985. - 1999. (tab. 4).

Razne kombinacije parametara i varijabli rezultirale su desetcima simuliranih karata zemljišnog pokrova za 2013. godinu. Zbog stohastične naravi modela tri karte dobivene optimalnim parametrima spojene su modalnom funkcijom u jednu konačnu kartu zemljišnog pokrova za 2013. godinu (sl. 5).

Ukupno slaganje triju karata u odnosu na referentnu variralo je između $82,2 \%$ i 82,87 \%. Kom-

Tab. 4 Transition matrix of LULC in Požega-Slavonia County for the period of 1985-1999

Tab. 4. Tranzicijska matrica LULC-a u Požeško-slavonskoj županiij 1985. - 1999.

\begin{tabular}{|l|l|c|c|c|c|}
\hline & \multicolumn{5}{|c|}{1999} \\
\hline & $\begin{array}{l}\text { Water / } \\
\text { Voda }\end{array}$ & $\begin{array}{l}\text { Built-up / } \\
\text { Izgrađeno }\end{array}$ & $\begin{array}{l}\text { Crops and } \\
\text { soil / } \\
\text { Usjevi i tlo }\end{array}$ & $\begin{array}{l}\text { Grass and } \\
\text { shrubs / } \\
\text { Trava i šikara }\end{array}$ & $\begin{array}{l}\text { Forest / } \\
\text { Šuma }\end{array}$ \\
\hline $\begin{array}{l}\text { Water / } \\
\text { Voda }\end{array}$ & 0.907 & 0.000 & 0.087 & 0.006 & 0.000 \\
\hline $\begin{array}{l}\text { Built-up / } \\
\text { Izgrađeno }\end{array}$ & 0.000 & 0.980 & 0.004 & 0.014 & 0.002 \\
\hline $\begin{array}{l}\text { Crops and } \\
\text { soil / } \\
\text { Usjevi i tlo }\end{array}$ & 0.000 & 0.006 & 0.662 & 0.285 & 0.047 \\
\hline $\begin{array}{l}\text { Grass and } \\
\text { shrubs / } \\
\text { Trava i šikara }\end{array}$ & 0.000 & 0.002 & 0.155 & 0.627 & 0.216 \\
\hline $\begin{array}{l}\text { Forest / } \\
\text { Šma }\end{array}$ & 0.001 & 0.000 & 0.016 & 0.036 & 0.946 \\
\hline
\end{tabular}

Source: derived from the EarthExplorer data

Izvor: obrada podataka sa stranice EarthExplorer 


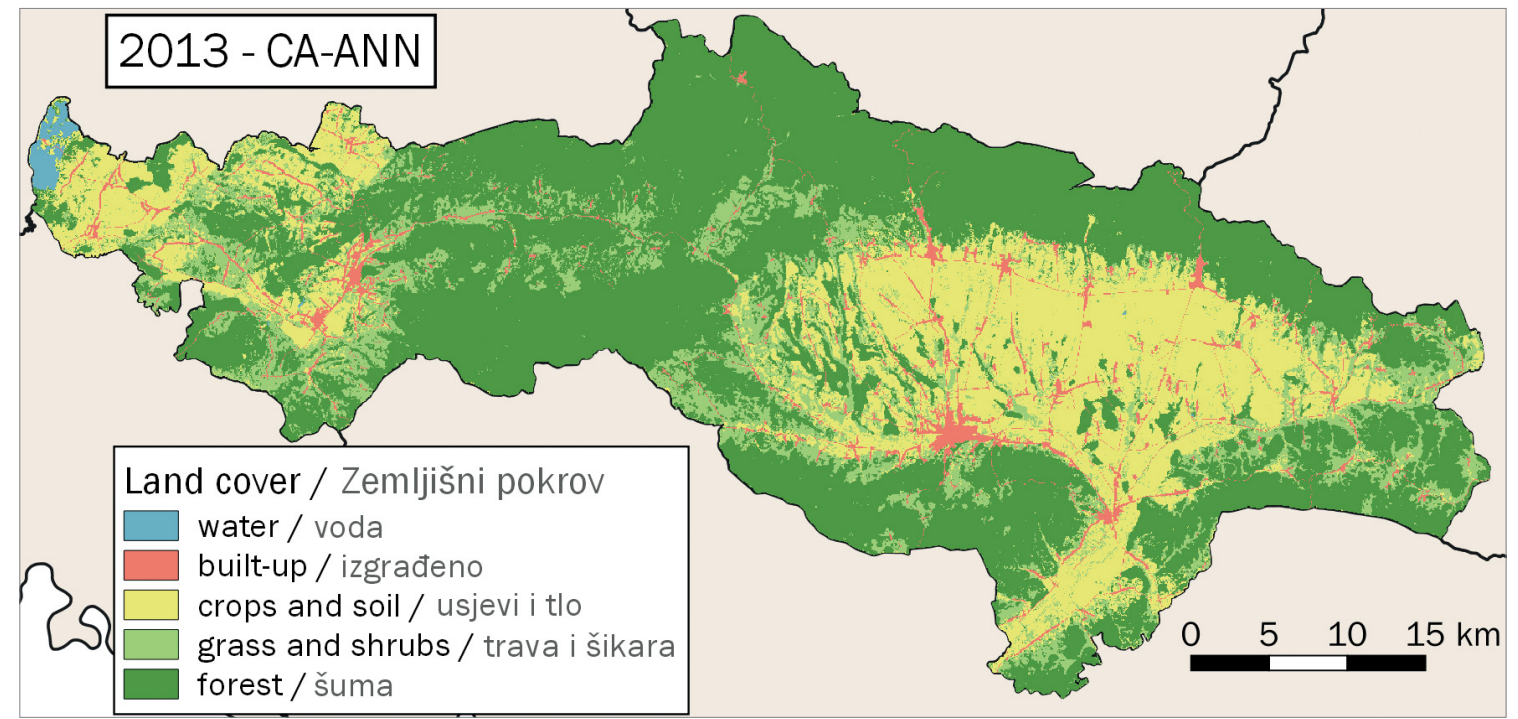

Fig. 5 CA-ANN simulation of land cover in Požega-Slavonia County for 2013

SI. 5. CA-ANN simulacija zemljišnog pokrova u Požeško-slavonskoj županiji za 2013.

Source: derived from the EarthExplorer data; DARH, 2005.

Izvor: obrada podataka sa stranice EarthExplorer; DARH, 2005.

increased their overall agreement to $83.5 \%$. The simulation models had slightly better results than the null model, but their overall validation results were similar. Much bigger differences between the models' performance were found in the prediction of quantity and location of land cover classes. Namely, all simulation models better predicted quantities of classes than the null model, while the null model better predicted locations of classes than the simulation models (Fig. 6).

It was more important to assess the accuracy of simulated changes than overall land cover. A comparison of net changes between observed and simulated maps revealed that the simulation model correctly predicted the tendency of changes in all classes except crops and soil. It predicted the largest net change especially well-an increase of forest cover (observed $=6.3 \%$, simulated $=5.3 \%$ ).

Using the three-way map comparison approach for validation of simulated LULC, it was theoretically possible to compute 125 combinations of agreement or disagreement for 5 classes, but they were aggregated instead (Fig. 7). The largest error was due to the changes simulated as persistence (12.2\%). The figure of merit of simulated LULC was $20.2 \%$. binacija triju karata povećala je njihovo ukupno slaganje na 83,5 \%. Simulacijski modeli imali su nešto bolje rezultate od nul-modela, ali su ukupni rezultati validacije bili slični. Mnogo veće razlike u performansama modela bile su u simulaciji kvantitete i lokacija klasa zemljišnog pokrova. Naime, svi simulacijski modeli bolje su predvidjeli kvantitetu klasa nego nul-model, dok je nul-model bolje predvidio njihove lokacije nego simulacijski modeli (sl. 6).

Važnije je bilo procijeniti točnost simuliranih promjena nego ukupnoga zemljišnog pokrova. Usporedba neto promjena između referentnih i simuliranih karata otkrila je da je simulacijski model točno predvidio tendenciju promjena svih klasa osim usjeva i tla. Osobito je dobro predvidio najznačajniju promjenu, porast površine šuma (opaženo $=6,3 \%$, simulirano $=5,3 \%$ ).

Pristupom trostruke usporedbe karata za validaciju simuliranih promjena načina korištenja zemljišta i zemljišnog pokrova teoretski se moglo dobiti 125 kombinacija slaganja ili neslaganja za 5 klasa, ali su one umjesto toga grupirane (sl. 7). Najveća se pogreška dogodila zbog promjena simuliranih kao perzistencije (12,2\%). Faktor kakvoće simuliranoga LULC-a bio je 20,2 \%.
Simulacijski model promjena zemljišnog pokrova u postsocijalističkom perifernom ruralnom području: Požeško-slavonska županija, Hrvatska 
HRVATSKI GEOGRAFSKI GLASNIK

81/1,31-59 (2019.)

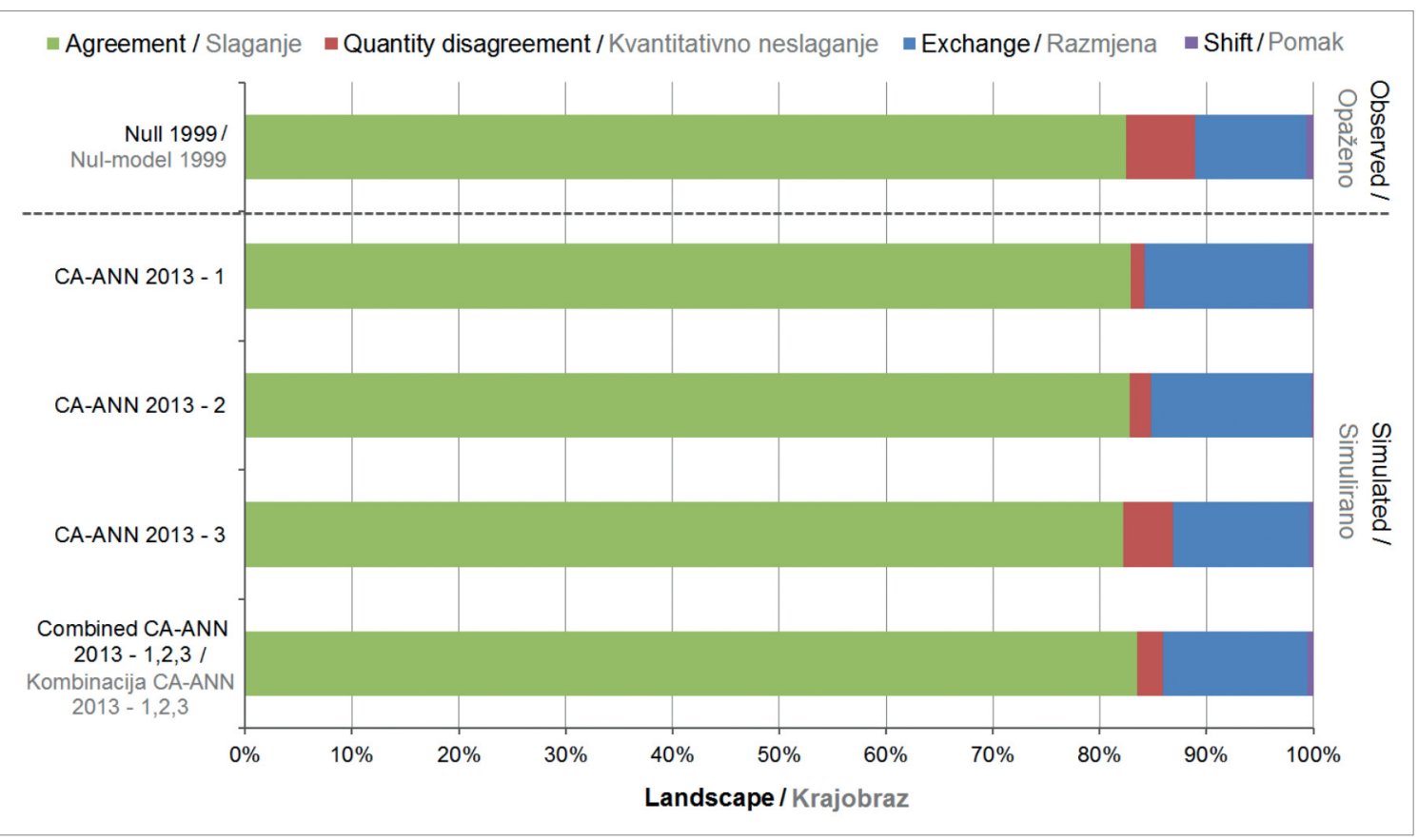

Fig. 6 Overall quantity and allocation disagreement of land cover classes in simulated versus observed for 2013 SI. 6. Ukupno kvantitativno i lokacijsko neslaganje klasa zemljišnog pokrova simuliranih i nul-modela za 2013.

Source: derived from the EarthExplorer data

Izvor: obrada podataka sa stranice EarthExplorer

Persistence simulated correctly $=79.29 \%$ I

Točno simulirane perzistencije $=79,29 \%$

Persistence simulated as change /

Perzistencija simulirana kao promjena

Change simulated as change to wrong category /

Promjena simulirana kao promjena u pogreśnu kategoriju

Change simulated correctly /

Točno simulirana promjena

Change simulated as persistence /

Promjena simulirana kao perzistencija

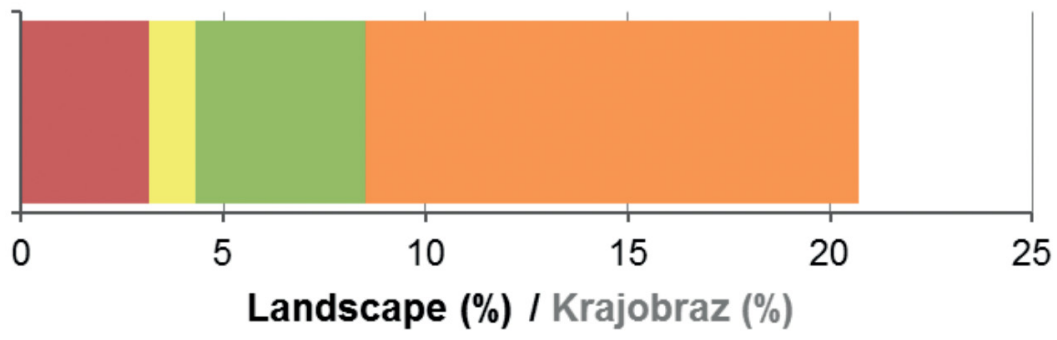

Fig. 7 Components of agreement and disagreement of simulated LULC Using a three-way map comparison approach SI. 7. Sastarnice slaganja i neslaganja simuliranoga LULC-a uporabom pristupa trostruke usporedbe karata

Source: derived from the EarthExplorer data Izvor: obrada podataka sa stranice EarthExplorer 
The validation map shows the spatial distribution of the agreement and disagreement components of the simulated LULC (Fig. 8). The most accurate predictions of LULC were in southern parts of Pakračka gora, where they were the largest and relatively linear due to the total land abandonment after the war.
Validacijska karta prikazuje prostorni raspored sastavnica slaganja i neslaganja simuliranih promjena načina korištenja zemljišta i zemljišnog pokrova (s1. 8). Najtočnija predviđanja tih promjena bila su u južnim dijelovima Pakračke gore, gdje su bile najveće i relativno linearne zbog potpuna napuštanja zemljišta nakon rata.

Simulation Model of Land Cover

Changes in a PostSocialist Peripheral

Rural Area: Požega-

Slavonia County, Croatia

Simulacijski model promjena zemljišnog pokrova $\mathrm{u}$ postsocijalističkom perifernom ruralnom području:

Požeško-slavonska županija, Hrvatska

Fig. 8. Spatial distribution of components of agreement and disagreement of the simulated LULC in PožegaSlavonia County for 2013

SI. 8. Prostorna raspodjela

sastarnica slaganja

neslaganja simuliranoga

LULC-a u Požeško-slavonskoj Županiiji za 2013.

Legend:

1 - change simulated as change to wrong category,

2 - change simulated correctly,

3 - change simulated as persistence,

4 - persistence simulated as change,

5 - persistence simulated correctly Legenda:

- promiena simulirana kao promjena u pogrešnu kategoriju,

2 - točno simulirana promjena, 3 - promjena simulirana kao perzistencija

4 - perzistencija simulirana kao promjena,

5 - točno simulirana perzistencija

Source: derived from the EarthExplorer data; DARH,

2005.

Izvor: obrada podataka sd stranice EarthExplorer; DARH,

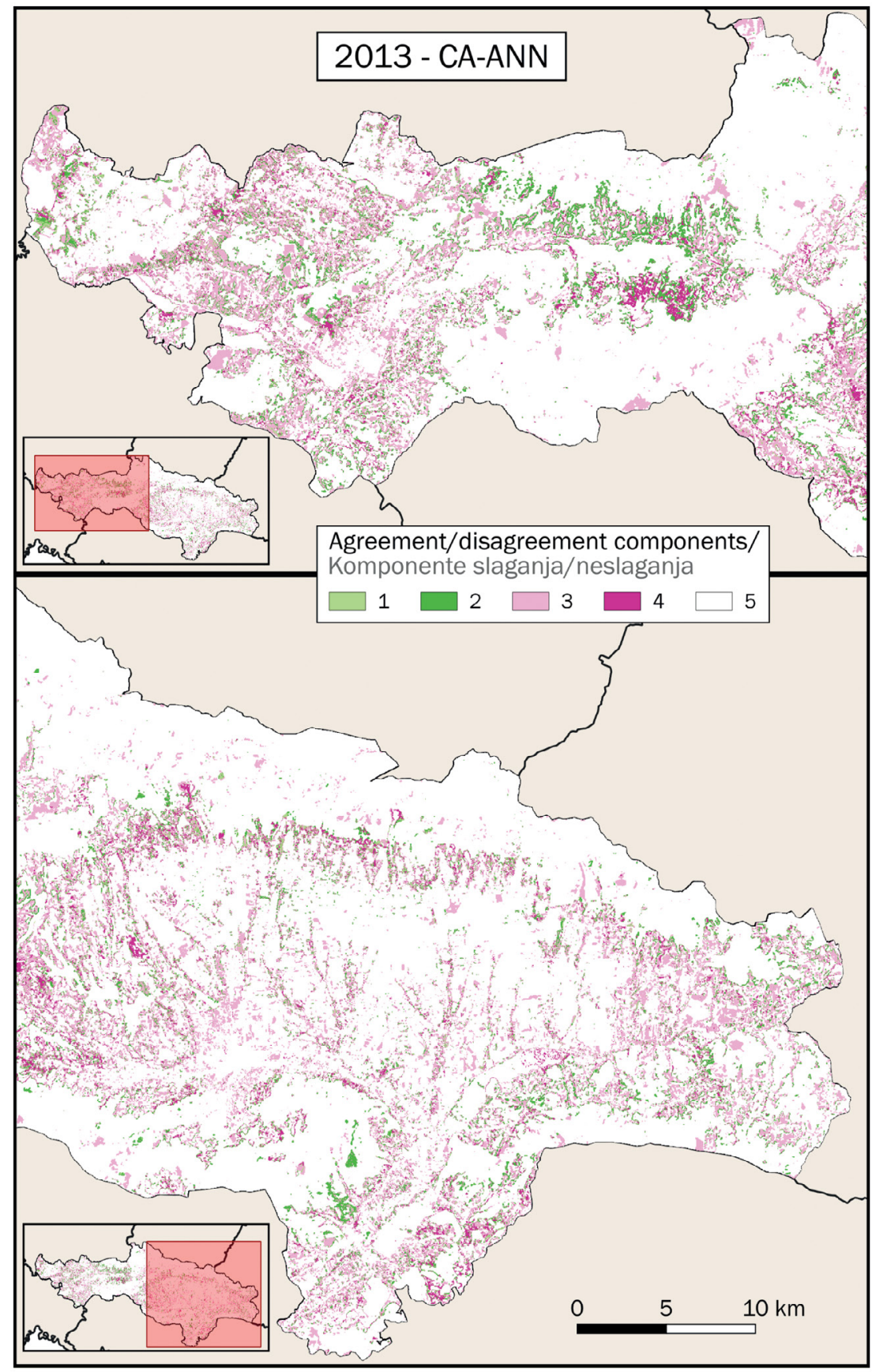


HRVATSKI

GEOGRAFSKI

GLASNIK

81/1,31-59 (2019.)
Final simulation of land cover changes (2013-2027)

Transition probabilities for the period of 20132027 were computed with the Markov chain analysis from the period of 1999-2013 (Tab. 5).

Model calibration was done with the parameters ascertained as optimal in the test model, while dynamic social variables were changed (e.g. population density from 2011). After running the CAANN simulation, three of the produced maps for 2027 were selected and combined using the modal function, as in the test model (Fig. 9).

Regarding the fact that validation showed that the simulation models better predicted quantity rather than the location of LULC, the quantitative analysis likely deserves more attention (Tab. 6).

According to the CA-ANN model, forests could cover almost 115 thousand hectares, i.e. $63 \%$ of the surface of the county, by 2027. Grasslands could have only half of the surface area (7.9\%) that they covered in 1985 (13.7\%). A small predicted reduction of agricultural areas $(-1.3 \%)$ could imply polarisation in agricultural development-extensifica-
Konačna simulacija promjena zemljišnog pokrova (2013. - 2027.)

Tranzicijske vjerojatnosti za razdoblje 2013. 2027. izračunane su metodom Markovljevih lanaca iz razdoblja 1999. - 2013. (tab. 5).

Model je kalibriran parametrima koji su potvrđeni kao optimalni u testnom modelu, dok su dinamične socijalne varijable promijenjene (npr. gustoća naseljenosti iz 2011.). Nakon provedene simulacije CA-ANN-a za 2027. godinu izabrane su tri karte i spojene modalnom funkcijom kao u testnom modelu (sl. 9).

S obzirom na to da je validacija pokazala kako su simulacijski modeli bolje predviđali kvantitetu od lokacija promjena načina korištenja zemljišta i zemljišnog pokrova, kvantitativna analiza zaslužuje više pozornosti (tab. 6).

Prema modelu CA-ANN šume bi do 2027. godine mogle pokrivati gotovo 115 tisuća hektara, tj. 63 \% površine županije. Trava i šikara mogle bi zauzimati samo polovinu površine $(7,9 \%)$ koju su zauzimale 1985. (13,7 \%). Predviđeno neznatno smanjenje poljoprivrednih površina $(-1,3 \%)$ moglo bi podrazumijevati polarizaciju agrarnog razvo-

Tab. 5 Transition matrix of LULC in Požega-Slavonia County for the period of 1999-2013

Tab. 5. Tranzicijska matrica LULC-a u Požeško-slavonskoj županiji 1999. - 2013.

\begin{tabular}{|l|l|c|c|c|c|}
\hline & \multicolumn{5}{|c|}{2013} \\
\hline & $\begin{array}{l}\text { Water / } \\
\text { Voda }\end{array}$ & $\begin{array}{l}\text { Built-up / } \\
\text { Izgrađeno }\end{array}$ & $\begin{array}{l}\text { Crops and } \\
\text { soil / } \\
\text { Usjevi i tlo }\end{array}$ & $\begin{array}{l}\text { Grass and } \\
\text { shrubs / } \\
\text { Trava i šikara }\end{array}$ & $\begin{array}{l}\text { Forest / } \\
\text { Šuma }\end{array}$ \\
\hline $\begin{array}{l}\text { Water / } \\
\text { Voda }\end{array}$ & 0.704 & 0.000 & 0.271 & 0.013 & 0.012 \\
\hline $\begin{array}{l}\text { Built-up / } \\
\text { Izgrađeno }\end{array}$ & 0.000 & 0.969 & 0.007 & 0.014 & 0.010 \\
\hline $\begin{array}{l}\text { Crops and } \\
\text { soil / } \\
\text { Usjevi i tlo }\end{array}$ & 0.001 & 0.003 & 0.839 & 0.129 & 0.028 \\
\hline $\begin{array}{l}\text { Grass and } \\
\text { shrubs / } \\
\text { Trava i šikara }\end{array}$ & 0.000 & 0.001 & 0.197 & 0.443 & 0.358 \\
\hline $\begin{array}{l}\text { Forest / } \\
\text { Šma }\end{array}$ & 0.000 & 0.000 & 0.005 & 0.031 & 0.964 \\
\hline
\end{tabular}

Source: derived from the EarthExplorer data

Izvor: obrada podataka sa stranice EarthExplorer 


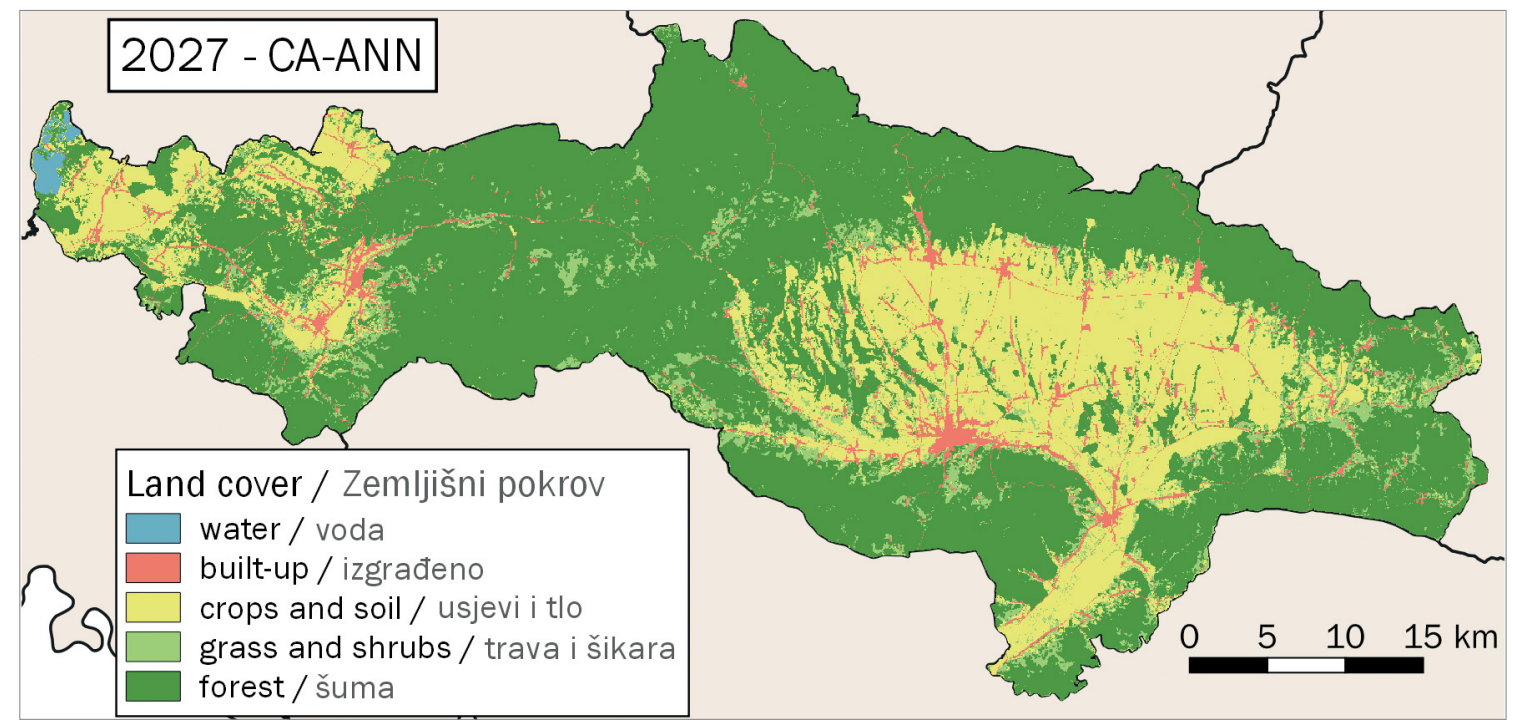

Simulation Model of Land Cover

Changes in a PostSocialist Peripheral

Rural Area: Požega-

Slavonia County, Croatia

Simulacijski model promjena zemljišnog pokrova u postsocijalističkom perifernom ruralnom području: Požeško-slavonska županija, Hrvatska

Fig. 9 CA-ANN simulation of land cover in Požega-Slavonia County for 2027

SI. 9. CA-ANN simulacija zemljišnog pokrova u Požeško-slavonskoj županiji za 2027.

Source: derived from the EarthExplorer data; DARH, 2005.

Izvor: obrada podataka sa stranice EarthExplorer; DARH, 2005.

tion in less favourable areas and intensification in Požega Basin, where the natural (flat terrain, fertile soil) and social conditions (relatively stable population, better transport connectivity) are better for agriculture. ja - ekstenzifikaciju u nepovoljnim područjima te intenzifikaciju u Požeškoj kotlini, gdje su prirodni (ravan reljef, plodna tla) i društveni uvjeti (relativno stabilno stanovništvo, bolja prometna povezanost) povoljniji za poljoprivredu.

Tab. 6 Land cover structure and simulated net LULC in the period of 2013-2027

Tab. 6. Strukłura zemliišnog pokrova i simulirane neto promjene načina korištenja zemliǰ̌ta i zemliǰšnog pokrova u razdobliu 2013. - 2027.

\begin{tabular}{|l|c|c|c|c|c|c|}
\hline & \multicolumn{2}{|c|}{$\mathbf{2 0 1 3}$} & \multicolumn{2}{c|}{2027} & \multicolumn{2}{c|}{$\Delta$ 2013-2027 } \\
\hline & ha & $\%$ & ha & $\%$ & ha & $\%$ \\
\hline $\begin{array}{l}\text { Water / } \\
\text { Voda }\end{array}$ & 677.67 & 0.37 & 643.57 & 0.35 & -34.10 & -0.02 \\
\hline $\begin{array}{l}\text { Built-up / } \\
\text { Izgrađeno }\end{array}$ & 7195.12 & 3.95 & 7141.23 & 3.92 & -53.89 & -0.03 \\
\hline $\begin{array}{l}\text { Crops and } \\
\text { soil / Usjevi i } \\
\text { tlo }\end{array}$ & 47924.58 & 26.31 & 45513.25 & 24.98 & -2411.33 & -1.32 \\
\hline $\begin{array}{l}\text { Grass and } \\
\text { shrubs / Trava i } \\
\text { šikara }\end{array}$ & 25434.27 & 13.96 & 14379.36 & 7.89 & -11054.90 & -6.07 \\
\hline $\begin{array}{l}\text { Forest / } \\
\text { Šma }\end{array}$ & 100942.30 & 55.41 & 114496.50 & 62.85 & 13554.23 & 7.44 \\
\hline
\end{tabular}

Source: derived from the EarthExplorer data

Izvor: obrada podataka sa stranice EarthExplorer 
HRVATSKI

GEOGRAFSKI

GLASNIK

81/1,31-59 (2019.)
Allocation of simulated LULC in the period of 2013-2027 was similar to that of the previous period (Fig. 10). Therefore, the location-validity of the model could be considered satisfactory at the coarse spatial level.
Razmještaj simuliranih promjena načina korištenja zemljišta i zemljišnog pokrova za razdoblje 2013. - 2027. bio je sličan kao za prethodno razdoblje (sl. 10). Prema tome, lokacijska vjerodostojnost modela na grubljoj prostornoj razini može se ocijeniti zadovoljavajućom.

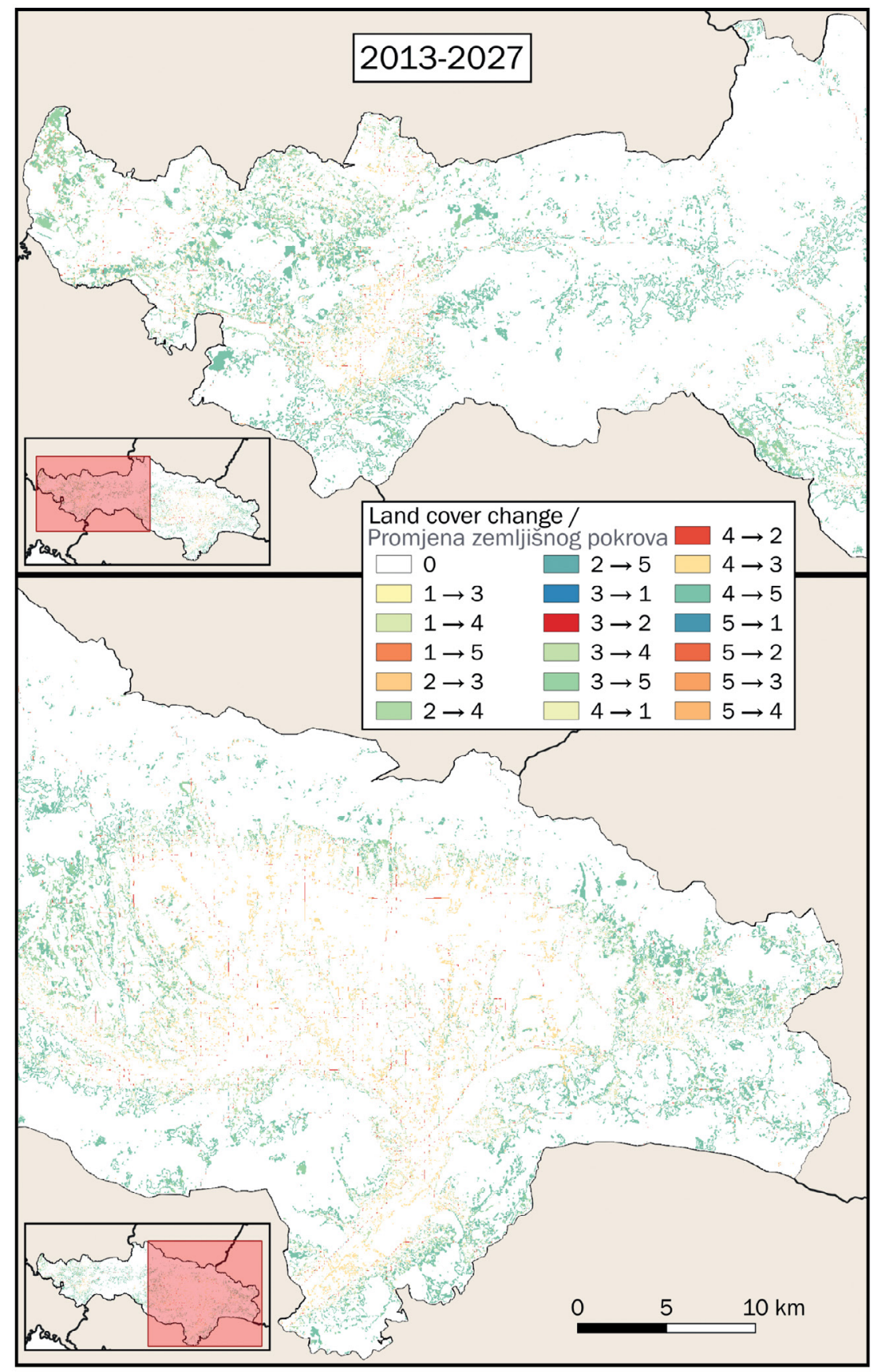

Fig. 10 Simulated land cover changes in Požega-Slavonia County for the period of 2013-2027

SI. 10. Simulirane promiene zemlijšnog pokrova u Požeškoslavonskoj županiij 2013. - 2027

Legend:

0 - no change, 1 -water 2 - built-up, 3 - crops and soil, 4 - grass and shrubs, 5 - forest Legenda:

0 - bez promiene, 1 -voda 2-izgrađeno, 3- usjevi i tlo, 4 - trava i šikara, 5 - šuma

Source: derived from the EarthExplorer data; DARH, 2005.

Izvor: obrada podataka sa stranice EarthExplorer; DARH 2005. 


\section{Evaluation of methods and techniques}

Hybrid classification of images acquired by remote sensing was used for detection of land cover. The high overall accuracy achieved (over 95\%) confirmed that this is one of the most accurate classification methods (Horning, 2004).

Conversely, validation of simulation models depends highly on the accuracy of reference data, and comparisons between different models are relative (Pontius et al., 2008). Furthermore, many studies are lacking validation entirely (Pontius et al., 2004; Verburg et al.,2004; Pontius et al., 2008). Although the comparison to a null model is the simplest validation method, it is very rigid, because it is sometimes an insuperable barrier (Pontius et al., 2004). Pontius et al. (2008) compared 13 simulation model applications, and 6 of them performed worse than the respective null model. The figure of merit in this study was $20.2 \%$, which is the average in comparison to the other results in Pontius et al. (2008), and better than that shown in more recent studies (Memarian et al., 2012; Sloan and Pelletier, 2012). However, Pontius et al. (2008) found that figure of merit of the LULC model depends on the amount of LULC, where models observing greater LULC have a greater figure of merit. This study confirmed that claim because LULC were observed in $17 \%$ of the area, which is also average.

Regarding quantity and location disagreement, results showed that the simulation models better predicted quantity rather than the location of LULC, which corresponds to previous studies (Memarian et al., 2012).

Besides the amount of LULC, their trends also impact model performance. If the trends are linear (e.g. deforestation in developing countries), the model will perform better. Here, non-linear changes due to time lags in the process of secondary succession, which are hard to incorporate into a model, were problematic. This research area is unique in comparison to previous studies, in the manner that there was an observed decrease

\section{Evaluacija metoda i tehnika}

Hibridna klasifikacija snimki prikupljenih daljinskim istraživanjima upotrijebljena je za utvrđivanje zemljišnog pokrova. Visoka ukupna postignuta točnost (preko $95 \%$ ) potvrdila je da je to jedna od najtočnijih metoda klasifikacije (Horning, 2004).

S druge strane, validacija simulacijskih modela uvelike ovisi o točnosti referentnih podataka, a usporedbe između različitih modela su relativne (Pontius i dr., 2008). Nadalje, u brojnim istraživanja uopće nema validacije (Pontius i dr., 2004; Verburg i dr., 2004; Pontius i dr., 2008). Iako je usporedba s nul-modelom najjednostavnija metoda validacije, vrlo je stroga jer je katkad nepremostiva prepreka (Pontius i dr., 2004). Pontius i dr. (2008) usporedili su 13 primijenjenih simulacijskih modela, od kojih je 6 bilo lošije od odgovarajućega nul-modela. Faktor kakvoće u ovom je istraživanju bio $20,2 \%$, što je prosječno u usporedbi s drugim rezultatima u Pontius i dr. (2008), a bolje nego u nekim novijim istraživanjima (Memarian i dr., 2012; Sloan i Pelletier, 2012). Međutim, Pontius i dr. (2008) otkrili su da faktor kakvoće modela LULC-a ovisi o količini promjena načina korištenja zemljišta i zemljišnog pokrova, pri čemu su modeli s većim promjenama imali veći faktor kakvoće. Ovo je istraživanje potvrdilo tu tvrdnju jer su su dotične promjene opažen na $17 \%$ područja, što je također prosječno.

Što se tiče kvantitativnog i lokacijskog neslaganja, rezultati su pokazali da su simulacijski modeli bolje predviđali količinu od lokacija promjena, što odgovara prethodnim istraživanjima (Memarian i dr., 2012).

Osim količine promjena, njihovi trendovi također utječu na izvedbu modela. Ako su trendovi linearni (npr. deforestacija u slabije razvijenim zemljama), model će biti uspješniji. Ovdje su bile problematične nelinearne promjene zbog vremenskog zaostajanja tijekom sekundarne sukcesije, koje je teško ugraditi u model. Područje istraživanja je jedinstveno u odnosu na prethodna
Simulation Model of Land Cover Changes in a PostSocialist Peripheral Rural Area: PožegaSlavonia County, Croatia

Simulacijski model promjena zemljišnog pokrova u postsocijalističkom perifernom ruralnom području: Požeško-slavonska županija, Hrvatska 
of built-up land, which is considered to be a very unusual change (Verburg and Overmars, 2007).

The number of land cover classes significantly impacts the accuracy of the simulation models. With the introduction of every new class, the probability of error exponentially increases. Hence, dichotomous models (urban/non-urban, forest/non-forest) perform better than ones using multiple classes ( $\mathrm{Li}$ and Yeh, 2002). In this study, there were five land cover classes, which were enough to determine the most relevant processes of extensification (crops-grass-forest) and intensification in the study area. This number of classes was average in comparison to previous studies (Pontius et al., 2008).

Scientists are constantly trying to find ways to improve the results of the validation of LULC simulation models. A popular method is a multi-resolution validation, in which a model is validated at different spatial resolutions. Predicted maps at coarser resolution have a higher agreement with reference maps than at finer resolution (Pontius et al., 2004). However, this might indicate that the model is scale-dependent, rather than more accurate. We made a combination of simulation results to improve the overall accuracy because similar approaches in classification have yielded promising results (Chen, 2008). Considering that the model is stochastic, combination increases the probability of a correct simulation (e.g. if two models predicted the persistence of class $A$, and a third model predicted change from $A$ to $B$, the combined result would retain persistence, which is more probable). The improvement due to the combination was not statistically significant, and the figure of merit of the combined map was even smaller than in some specific maps. This can be explained by components of agreement and disagreement because specific maps better predicted changes, but they did a worse job of predicting persistence than the combined map. Combination improved the overall visual balance of the maps. In the future research, it would be interesting to include pan-sharpening methods during preprocessing of input images and examine its effects on classification and LULC model accuracy (Gašparović and Jogun, 2018). istraživanja jer je opaženo smanjenje izgrađenog zemljišta, što se smatra vrlo neobičnom promjenom (Verburg i Overmars, 2007).

Broj klasa zemljišnog pokrova značajno utječe na točnost simulacijskih modela. Uvođenjem svake nove klase vjerojatnost pogreške eksponencijalno raste. Stoga su dihotomni modeli (urbano/neurbano, šuma/ostalo) učinkovitiji od onih s većim brojem klasa (Li i Yeh, 2002). U ovom je istraživanju bilo pet klasa, što je bilo dovoljno za utvrđivanje najvažnijih procesa ekstenzifikacije (usjevi - travnjaci - šume) i intenzifikacije u istraženom području. Broj klasa bio je prosječan u usporedbi s prethodnim istraživanjima (Pontius i dr., 2008).

Znanstvenici stalno pokušavaju pronaći načine kako poboljšati rezultate validacije simulacijskih modela promjena načina korištenja zemljišta i zemljišnog pokrova. Popularna metoda je multirezolucijska validacija u kojoj se model vrednuje u različitim prostornim rezolucijama. Simulirane karte u grubljoj rezoluciji imaju veće slaganje s referentnim kartama nego u finijoj rezoluciji (Pontius i dr., 2004). Međutim, to prije može značiti da je model ovisan o mjerilu nego da je točniji. Ovdje je načinjena kombinacija rezultata simulacija kako bi se povećala ukupna točnost jer je sličan pristup u klasifikaciji dao obećavajuće rezultate (Chen, 2008). S obzirom na to da je model stohastičan, kombinacija povećava vjerojatnost točne simulacije (npr. ako su dva modela predvidjela perzistenciju klase $A$, a treći je model predvidio promjenu iz $A \mathrm{u} B$, kombinirani bi rezultat zadržao perzistenciju, što je vjerojatnije). Poboljšanje zbog kombinacije nije bilo statistički značajno, a faktor kakvoće kombinirane karte bio je čak manji od nekih pojedinačnih karata. To se može objasniti komponentama slaganja i neslaganja jer su specifične karte bolje simulirale promjene, ali su lošije simulirale perzistencije od kombinirane karte. Kombinacija je poboljšala ukupnu vizualnu ravnotežu karata. U budućnosti bi bilo zanimljivo uključiti metode izoštravanja u predobradu ulaznih snimka $\mathrm{i}$ ispitati njihov utjecaj na klasifikaciju i točnost LULC modela (Gašparović i Jogun, 2018). 


\section{Evaluation of results}

Today, post-socialist Croatia has similar problems with land abandonment in peripheral rural areas to those of other countries from the former Eastern Bloc, e.g. Latvia (Ruskule et al., 2012), and Slovakia (Némethová et al., 2014).

In the mountainous parts of Požega-Slavonia County, which were used for low-intensity agriculture 30 years ago, the dominant process was secondary succession, which will probably result in total afforestation by 2030. Similar processes of land abandonment were documented in previous studies in Croatia (Cvitanović, 2014), in which they were explained by social restructuring, i.e. deagrarianisation and industrialisation. Afforestation in Požega-Slavonia County in the period of 1985-2013 was influenced by depopulation, unfavourable natural conditions, transport isolation, deep political and economic changes (collapse of socialism, transition, $\mathrm{EU}$ accession), war, unsuccessful privatisation, etc.; which corresponds to more recent studies (Ruskule et al., 2012; Griffiths et al., 2013; Cvitanović et al., 2016).

The relation between afforestation/share of forest cover and types of settlements demonstrated that LULC could be used as an indicator of finescale development trends. Depopulation is one of the most important driving forces of land use extensification and overall development problems in Požega-Slavonia County. Spatial plans were recently updated with acts regarding land as an unrenewable resource, but new data on LULC trends and population dynamics are lacking. Accurate input data in development strategies and documents are the first step in their successful realisation, so they should be improved. This paper contains a lot of data on LULC that can be used in new spatial plans and strategies of Požega-Slavonia County.

Active strategies of land use and land cover management could be intensification, extensification, and afforestation. Sometimes, however, the most beneficial option is "re-wilding", i.e. passive management of ecological succession with the aim to restore natural ecosystem processes and reduce human control of landscapes (Navarro and Pereira, 2012). In any case, the decision on land use and

\section{Evaluacija rezultata}

Današnja postsocijalistička Hrvatska ima slične probleme s napuštanjem zemljišta u perifernim ruralnim područjima kao druge države bivšega istočnog bloka, npr. Latvija (Ruskule i dr., 2012) i Slovačka (Némethová i dr., 2014).

U gorskim predjelima Požeško-slavonske županije koji su bili iskorištavani za ekstenzivnu poljoprivredu prije 30 godina prevladavajući proces bila je sekundarna sukcesija koja će vjerojatno rezultirati potpunom aforestacijom do 2030. Slični procesi napuštanja zemljišta zabilježeni su u prethodnim istraživanjima u Hrvatskoj (Cvitanović, 2014), u kojima su objašnjeni socijalnim prestrukturiranjem, tj. deagrarizacijom i industrijalizacijom. Aforestacija u Požeško-slavonskoj županiji u razdoblju 1985. - 2013. bila je pod utjecajem depopulacije, nepovoljnih prirodnih uvjeta, prometne izolacije, korjenitih političkih i gospodarskih promjena (raspad socijalizma, tranzicija, pristup EUu), rata, neuspješne privatizacije itd., što se poklapa s novijim istraživanjima (Ruskule i dr., 2012; Griffiths i dr., 2013; Cvitanović i dr., 2016).

Odnos između aforestacije (udjela šumskog pokrova) i tipova naselja pokazao je da promjene načina korištenja zemljišta i zemljišnog pokrova mogu biti indikator razvojnih trendova na lokalnoj razini. Depopulacija je jedna od najvažnijih pokretačkih sila ekstenzifikacije zemljišta i sveukupnih razvojih problema u Požeško-slavonskoj županiji. Prostorni planovi nedavno su nadopunjeni aktima o zemljištu kao neobnovljivom resursu, ali nedostaju novi podatci o trendovima LULC-a i kretanju stanovništva. Točni ulazni podatci u razvojnim strategijama i dokumentima prvi su korak u njihovoj uspješnoj provedbi, stoga se trebaju poboljšati. Ovo istraživanje sadrži mnogo podataka o promjenama načina korištenja zemljišta i zemljišnog pokrova koji se mogu iskoristiti u novim prostornim planovima i strategijama Požeško-slavonske županije.

Aktivne strategije upravljanja načinom korištenja zemljišta i zemljišnim pokrovom mogu biti intenzifikacija, ekstenzifikacija i aforestacija. Međutim, katkad je najisplativije pasivno prepuštanje prirodnom tijeku razvoja, tzv. renaturalizaciji (engl. re-wilding) kako bi se obnovili prirodni procesi u ekosustavu i smanjio ljudski utjecaj na pejzaž (Navarro i Pereira, 2012). U svakom slučaju, odluka o strategiji razvoja korištenja
Simulation Model of Land Cover Changes in a PostSocialist Peripheral Rural Area: PožegaSlavonia County, Croatia

Simulacijski model promjena zemljišnog pokrova u postsocijalističkom perifernom ruralnom području: Požeško-slavonska županija, Hrvatska 
GEOGRAFSKI

GLASNIK

81/1,31-59 (2019.) land cover strategy should be based on regional studies (Rey Benayas et al., 2007). Remote sensing and GIS have had a great role in such studies, but they should not be seen as a panacea (Farrow and Winograd, 2001), nor are geographers and GIS-analysts the only competent experts in of LULC studies. An interdisciplinary, holistic approach is necessary, whereby simple visualisation of results should be the common language between all stakeholders (Herrmann and Osinski, 1999). The results of this study are meant to be used by the community, to help decide on the most appropriate land use management strategy.

\section{Conclusion}

This paper presented the application of integrated CA-ANN simulation model for analysis and prediction of land cover changes (MOLUSCE) in a post-socialist peripheral rural area.

The hybrid method of supervised classification of Landsat satellite images appeared to be very reliable, with a minimum overall accuracy of $95 \%$. Through comparison of classified maps, significant LULC in Požega-Slavonia County from 1985 to 2013 were observed. The class of forest had the highest increase in overall landscape, from 47\% in 1985 to 55\% in 2013. The class of soil and crops had the greatest decrease, from $35 \%$ in 1985 to $26 \%$ in 2013 . Thus, the main trend was secondary succession, characterised by the change from agricultural land to grass and shrubs in the period of 1985-1999, and a change from grass and shrubs to forest in the period of 1999-2013.

Statistical analysis of variables representing social and natural elements, which are correlated with LULC, revealed that it was possible to build a simulation model that explained historical trends and predicted future LULC in post-socialist peripheral rural areas. Using an example of forest cover and afforestation, it was proven that this LULC occurs more commonly in/around settlements that have the worst development trends and conditions (e.g. depopulation, mountainous terrain, traffic isolation, war consequences). Consequently, observed LULC could be used as an indicator of small-scale development trends. zemljišta i zemljišnog pokrova treba biti utemeljena na regionalnim studijama (Rey Benayas i dr., 2007). Daljinska istraživanja i GIS imaju nezaobilaznu ulogu u tim studijama, no oni nipošto nisu univerzalno rješenje (Farrow i Winograd, 2001) niti su geografi i GIS analitičari jedini kompetentni za studije o promjenama i utjecajima zemljišnog pokrova. Nužan je interdisciplinarni, holistički pristup, pri čemu jednostavna vizualizacija rezultata treba biti zajednički jezik među svim interesnim skupinama (Herrmann i Osinski, 1999). Rezultati ovoga istraživanja namijenjeni su zajednici kao pomoć u donošenju najprikladnije strategije upravljanja zemljišnim pokrovom.

\section{Zaključak}

Ovaj je rad predstavio primjenu integriranoga CA-ANN simulacijskog modela za analizu i projekciju promjena zemljišnog pokrova (MOLUSCE) u postsocijalističkom perifernom ruralnom području.

Hibridna metoda nadzirane klasifikacije satelitskih snimka Landsata pokazala se vrlo pouzdanom s ukupnom točnošću iznad $95 \%$. Usporedbom klasificiranih karata utvrđene su značajane promjene načina korištenja zemljišta i zemljišnog pokrova u Požeško-slavonskoj županiji od 1985. do 2013. Klasa šuma imala je najveći porast u cijelom pejzažu, s $47 \% 1985$. na $55 \%$ u 2013. Klasa tlo i usjevi imala je najveće smanjenje, s $35 \%$ 1985. na $26 \%$ 2013. Dakle, glavni trend bila je sekundarna sukcesija, obilježena promjenom iz poljoprivrednog zemljišta u travu i šikaru u razdoblju 1985. - 1999. te promjenom iz trave i šikare u šumu u razdoblju 1999. - 2013.

Statistička analiza varijabli koje predstavljaju društvene i prirodne elemente koreliranih s navedenim promjenama otkrila je da je moguće izgraditi simulacijski model koji je objasnio povijesne trendove i projicirao budući LULC u postsocijalističkom perifernim ruralnim područjima. Korištenjem primjera šumskog pokrova i aforestacije dokazano je da se takve promjene događaju češće u naseljima i oko naselja koja imaju najnepovoljnije razvojne trendove i uvjete (npr. depopulacija, gorski reljef, prometna izolacija, ratno naslijeđe). Posljedično, uočene promjene mogu se rabiti kao indikator razvojnih trendova na lokalnoj razini. 
The integrated CA-ANN model was proven to be one of the most efficient methods for simulating complex and non-linear LULC, which are specific for the research area. The simulated maps had a better agreement than the null model in comparison to observed maps, especially in predicting the quantity of LULC. The post-simulation combination of individual results slightly improved the overall agreement of simulated land cover with the observed, but not significantly. The main weakness of the model is that it is focused on pattern resemblance and acts like a "black box", so it would be appropriate to employ some kind of agent-based model in a similar area and compare their performance.

The simulation model predicted that forest will cover 63\% of Požega-Slavonia County by 2027 and that the mountainous zone between the Požega Basin and the Pakrac-Lipik area will be almost completely afforested. The potential dangers and opportunities of such LULC have been presented, therefore enabling the creation of management plans and scenarios. For example, in areas of Požega-Slavonia County that would become covered with forest, construction zones can be restricted to protect nature and let the land to become "wild" again; or they can be expanded, to stimulate immigration, along with other planning measures (e.g. subsidies for ecological agriculture).

Deep development problems in Požega-Slavonia County require focused and multi-sectoral strategy in which the realisation of spatial and regional development plans has an important role. Optimistically, this study would be useful in envisioning evidence-based policy and it is offered for evaluation, to all interested groups, in the hope that it will contribute to the welfare of society and nature in Požega-Slavonia County. Also, the study identified problems of LULC simulation modelling and management, which could be applied in other peripheral rural areas with similar development backgrounds.

This work was supported by the Croatian Science Foundation under Grant 4513 (Croatian Rural Areas: scenario-based approach to discuss planning and development, CRORURIS).
Integrirani CA-ANN model pokazao se kao jedna od najučinkovitijih metoda za simulaciju kompleksnog i nelinearnog LULC-a, koji je karakterističan za istraženo područje. Simulirane karte imale su veće slaganje nego nul-model u odnosu na opažene karte, posebno u projiciranju kvantitete promjena. Postsimulacijska kombinacija pojedinačnih rezultata neznatno je poboljšala ukupno slaganje simuliranoga zemljišnog pokrova u odnosu na opaženi. Glavni je nedostatak modela u tome što je usmjeren na slaganje uzoraka i što se ponaša kao „crna kutija” pa bi bilo prikladnije upotrijebiti neku vrstu agentnog modela u sličnom području te usporediti njihov učinak.

Simulacijski je model projicirao da će šume pokrivati 63 \% Požeško-slavonske županije do 2027. te da će gorska područja između Požeške kotline i pakračko-lipičkog kraja biti gotovo potpuno pošumljena. Predstavljene su potencijalne opasnosti i prilike takvih promjena načina korištenja zemljišta i zemljišnog pokrova omogućujući stvaranje razvojnih planova i scenarija. Na primjer, u područjima Požeško-slavonske županije koja će postati pokrivena šumom građevinske zone mogu se smanjiti radi zaštite prirode i prepuštanja zemljišta divljini ili se mogu proširiti radi poticanja imigracije usporedno s drugim planskim mjerama (npr. poticajima za ekološku poljoprivredu).

Duboki razvojni problemi u Požeško-slavonskoj županiji zahtijevaju usmjerenu i multisektorsku strategiju u kojoj realizacija prostornih i regionalnih razvojnih planova ima važnu ulogu. U najboljem slučaju ovo istraživanje može biti korisno u osmišljavanju politike utemeljene na dokazima te se daje na vrednovanje svim interesnim skupinama sa svrhom doprinosa dobrobiti društva i prirode u Požeško-slavonskoj županiji. Istraživanje je također uputilo na probleme simulacijskog modeliranja i upravljanja navednih promjena, što je primjenljivo na druga periferna ruralna područja sa sličnom razvojnom osnovom.

Ovaj rad poduprla je Hrvatska zaklada za znanost projektom 4513 (Primjena metode scenarija u planiranju i razvoju ruralnib područja Hrvatske, CRORURIS).

Simulation Model of Land Cover Changes in a PostSocialist Peripheral Rural Area: PožegaSlavonia County, Croatia

Simulacijski model promjena zemljišnog pokrova u postsocijalističkom perifernom ruralnom području: Požeško-slavonska županija, Hrvatska

Acknowledgement Zahvala 
GLASNIK

81/1,31-59 (2019.)

\section{Literature} Literatura
Alcantara, C., Kuemmerle, T., Baumann, M., Bragina, E., Griffiths, P., Hostert, P., Knorn, J., Mueller, D., Prishchepovs, A., Schierhorn, F., Sieber, A, Radeloff, V., 2013: Mapping the extent of abandoned farmland in Central and Eastern Europe using MODIS time series satellite data, Environmental Research Letters 8 (3), 38-47, DOI: 10.1088/17489326/8/3/035035.

Bański, J., Mazur, M., 2016: Classification of rural areas in Poland as an instrument of territorial policy, Land Use Policy 54, 1-17, DOI: 10.1016/j.landusepol.2016.02.005.

Baumann, M., Ozdogan, M., Kuemmerle, T., Wendland, K. J., Esipova, E., Radeloff, V. C., 2012: Using the Landsat record to detect forest-cover changes during and after the collapse of the Soviet Union in the temperate zone of European Russia, Remote Sensing of Environment 124, 174-184, DOI: 10.1016/j. rse.2012.05.001.

Beluszky, P., Sikos, T. T., 2008: Changing Village-Typology of Rural Settlements in Hungary at the Beginning of the Third Millennium, Discussion Papers 66, 5-53.

Bognar, A., 1999: Geomorfološka regionalizacija Hrvatske, Acta Geographica Croatica 34, 7-29.

Cosier, J., Šabec, E., Verlič, L., Ponikvar, A., Jenko, I., Klemenčič, K., Gostonj, U., Kežar, M., Gamse, M., Uršič, K., Pavlovič, J., Potočnik Slavič, I., 2014 Understanding disparities in Slovenian rural areas: various new indicators, $\mathrm{Ge}$ oadria 19 (2), 149-164.

CBS, 2011: Census 2011, Croatian Bureau of Statistics, http://www.dzs.hr/ (17. 6. 2018.)

CBS, 2015: Statistical Yearbook of the Republic of Croatia 2015, Croatian Bureau of Statistics, http://www.dzs. hr/Hrv_Eng/ljetopis/2015/sljh2015.pdf (17.6. 2018.)

Chen, D. 2008: A Standardized Probability Comparison Approach for Evaluating and Combining Pixel-based Classification Procedures, Photogrammetric Engineering E' Remote Sensing 74 (5), 1-9, DOI: 10.14358/PERS.74.5.601.

Cvitanović, M., 2014: Promjene zemljišnog pokrova i načina korištenja zemljišta u Krapinsko-zagorskoj županiji od 1991 do 2011., Hrvatski geografski glasnik 76 (1), 41-59.
Cvitanović, M., Blackburn, G. A., Jepsen, M. R., 2016: Characteristics and drivers of forest cover change in the post-socialist era in Croatia: evidence from mixed-methods approach, Regional Environmental Change 16 (1), 1-13, DOI 10.1007/s10113-016-0928-0.

Díaz, G. I., Nahuelhuala, L., Echeverríad, C., Maríne, S., 2011: Drivers of land abandonment in Southern Chile and implications for landscape planning, Landscape and Urban Planning 99, 207-217, DOI: 10.1016/j.landurbplan.2010.11.005.

Digitalni atlas Republike Hrvatske (DARH), GIS Data, Zagreb, 2005.

EarthExplorer, U.S. Geological Survey (USGS), http://earthexplorer.usgs.gov (18. 12.2018.)

EU-DEM, Copernicus, https://land.copernicus.eu/imagery-in-situ/eu-dem/ eu-dem-v1.1 (18. 12. 2018.)

Farrow, A., Winograd, M., 2001: Land use modelling at the regional scale: an input to rural sustainability indicators for Central America, Agriculture, Ecosystems and Environment 85, 249-268, DOI: 10.1016/S0167-8809(01)00192-X

Gašparović, M., Jogun, T., 2018: The effect of fusing Sentinel-2 bands on land-cover classification, International Journal of Remote Sensing, 39 (3), 822-841, DOI: 10.1080/01431161.2017.1392640.

GIS-Lab, 2018: Landscape change analysis with MOLUSCE - methods and algorithms, http://wiki.gis-lab.info/w/ Landscape_change_analysis_with_ MOLUSCE_-_methods_and_algorithms (08. 7.2018.)

Griffiths, P., Müller, D., Kuemmerle, T., Hostert, P., 2013: Agricultural land change in the Carpathian ecoregion after the breakdown of socialism and expansion of the European Union, Environmental Research Letters 8 (4), 1-12, DOI: 10.1088/1748-9326/8/4/045024.

Han, H., Yang, C., Song, J., 2015: Scenario Simulation and the Prediction of Land Use and Land Cover Change in Beijing, China, Sustainability 7, 4260-4279, DOI: $10.3390 /$ su 7044260 .

Herrmann, S., Osinski, E., 1999: Planning sustainable land use in rural areas at different spatial levels using GIS and modelling tools, Landscape and Urban Planning 46, 93-101, DOI: 10.1016/ S0169-2046(99)00050-X.
Horning, N., 2004: Land cover classification methods, Version 1.0. American Museum of Natural History, Center for Biodiversity and Conservation, New York.

Horvat, Z., 2013: Using Landsat Satellite Imagery to Determine Land Use/Land Cover Changes in Međimurje County, Croatia, Hrvatski geografski glasnik 75 (2), 5-28.

Jogun, T., Pavlek, K., Belić, T., Buhin, S. Malešić, N., 2017: Promjene zemljišnog pokrova u sjevernoj Hrvatskoj od 1981. do 2011. godine / Land cover changes in northern Croatia from 1981 to 2011, Hrvatski geografski glasnik 79 (1), 33-59. DOI: 10.21861/HGG.2017.79.01.02

Klufová, R., 2016: Current Delimitation and Typology of the Czech Countryside and its Importance for Rural Development, Eastern European Countryside 22, 229-251, DOI: 10.1515/eec-20160011.

Li, X., Yeh, A. G.-O., 2002: Neural-network-based cellular automata for simulating multiple land use changes using GIS, International Journal of Geographical Information Science 16 (4), 323-343, DOI: $10.1080 / 13658810210137004$.

Lukić, A., 2012: Mozaik izvan grada, Meridijani, Samobor.

Memarian, H., Balasundram, S. K., Talib, J. B., Sung, C. T. B., Sood, A. M., Abbaspour, K., 2012: Validation of CA-Markov for simulation of land use and cover change in the Langat Basin, Malaysia, Journal of Geographic Information System 4, 542-554, DOI: 10.4236/ jgis.2012.46059.

Mikhaylova, S. S., Budazhanayeva, Ts. M., Sarycheva, T. V., Bakumenko, L. P., 2015: Typology of Rural Territories of the Russian Federation Subjects, Mediterranean Journal of Social Sciences 6 (3), 205-211, DOI: 10.5901/mjss.2015. v6n3s7p205.

MOLUSCE, 2018: MOLUSCE Modules for Land Use Change Evaluation - Quick Help, https://github.com/ nextgis/molusce/blob/master/doc/en/ QuickHelp.pdf (08. 7. 2018.)

Navarro, L. M., Perreira, H. M., 2012: Rewilding Abandoned Landscapes in Europe, Ecosystems 15, 900-912, DOI: 10.1007/s10021-012-9558-7.

Némethová, J., Dubcová, A. Kramáreková H., 2014: The Impacts of the European Union's Common Agricultural Policy 
on Agriculture in Slovakia, Moravian geographical reports 22 (4), 51-64, DOI: 10.1515/mgr-2014-0023.

Nti, I. K., 2013: Geospatial Process Modelling for Land Use Cover Change, $\mathrm{PhD}$ dissertation, Auckland University of Technology.

Njegač, D., 2012: Istočna Hrvatska, in: Veliki atlas Hrvatske (ed. Opačić, V. T.), Mozaik knjiga, Zagreb, 328-343.

Pejnović, D., Kordej-De Villa, Ž., 2015: Demografski resursi kao indikator i čimbenik dispariteta u regionalnom razvoju Hrvatske, Društvena istraživanja 24 (3), 321-343, DOI: 10.5559/di.24.3.01.

Pijanowski, B. C., Brown, D. G., Shellito, B. A., Manik, G. A., 2002: Using neural networks and GIS to forecast land use changes: a Land Transformation Model, Computers, Environment and Urban Systems 26 (6), 553-575, DOI: 10.1016/ S0198-9715(01)00015-1.

Plieninger, T., Höchtl, F., Spek T., 2006: Traditional land-use and nature conservation in European rural landscapes, Environmental Science E Policy 9, 317-321, DOI: 10.1016/j.envsci.2006.03.001.

Pontius, R. G., Millones, M., 2011: Death to Kappa: birth of quantity disagreement and allocation disagreement for accuracy assessment, International Journal of Remote Sensing 32 (15), 4407-4429, DOI: 10.1080/01431161.2011.552923.

Pontius, R. G., Santacruz A., 2014: Quantity, exchange, and shift components of difference in a square contingency table, International Journal of Remote Sensing 35 (21), 7543-7554, DOI: 10.1080/2150704X.2014.969814.

Pontius, R. G., Huffaker, D., Denman, K., 2004: Useful techniques of validation for spatially explicit land-change models,
Ecological Modelling 179, 445-461, DOI: 10.1016/j.ecolmodel.2004.05.010.

Pontius, R. G., Boersma, W., Castella, J.C., Clarke, K., De Nijs, T., Dietzel, C., Duan, Z., Fotsing, E., Goldstein, N., Kok, K., Koomen, E., Lippitt, C. D., Mcconnell, W., Sood, A. M., Pijanowski, B., Pithadia, S., Sweeney, S., Trung, T. N., Veldkamp, A. T., Verburg, P. H., 2008: Comparing the input, output, and validation maps for several models of land change, Annals of Regional Science 42 (1), 11-37, DOI: 10.1007/s00168007-0138-2.

Rey Benayas, J. M., Martins, A., Nicolau, J. M., Schulz, J. J., 2007: Abandonment of agricultural land: an overview of drivers and consequences, $C A B$ Reviews Perspectives in Agriculture Veterinary Science Nutrition and Natural Resources 57 (2), 1-14, DOI: 10.1079/PAVSNNR20072057.

Rumelhart, D., Hinton, G., Williams, R., 1986: Learning internal representations by error propagation, in: Parallel distributed processing: explorations in the microstructures of cognition, Vol. 1 (eds. Rumelhart, D. E. and McClelland, J. L.), MIT Press, Cambridge, 318.

Ruskule, A., Nikodemus, O., Kasparinska Z., Kasparinskis R., Brümelis G., 2012: Patterns of afforestation on abandoned agriculture land in Latvia, Agroforestry Systems 85, 215-231, DOI: 10.1007/ s10457-012-9495-7.

Sloan, S., Pelletier, J., 2012: How accurately may we project tropical forest-cover change? A validation of a forward-looking baseline for REDD, Global Environmental Change 22, 440-453, DOI: 10.1016/j.gloenvcha.2012.02.001.

TA, 2011: The Territorial State and Perspectives of the European Union, 2011 update, Background document for the
Territorial Agenda of the European Union 2020, http://ec.europa.eu/regional_policy/sources/policy/what/territorial-cohesion/territorial_state_and_ perspective_2011.pdf (14. 7. 2018.)

Tudora, D., 2009: Typology of Moldavian rural settlements according to the population accessibility in relation to the polarizing centers of labor force in the fields specific to rural environment, $R o-$ manian Review of Regional Studies 5 (1), 67-76.

Václavík, T., Rogan, J., 2009: Identifying trends in land use/land cover changes in the context of post-socialist transformation in central Europe: a case study of the greater Olomouc region, Czech Republic, GIScience E Remote Sensing 46 (1), 54-76.

Van Schrojenstein Lantman, J., Verburg, P. H., Bregt, A., Geertman, S., 2011: Core Principles and Concepts in Land-Use Modelling: A Literature Review, in: Land-Use Modelling in Planning Practice (eds. Koomen, E. and Borsboom-Van Beurden, J.), Springer Science+Business Media B.V., Dordrecht, 35-57.

Verburg, P. H., Overmars, K. P., 2007: Dynamic simulation of land-use change trajectories with the CLUE-s model, in: Modelling Land-Use Change - Progress and Applications (eds. Koomen, E. i dr.), Springer, Dordrecht, 321-335.

Verburg, P. H., Schot, P. P., Dijst, M. J., Veldkamp, A., 2004: Land use change modelling: current practice and research priorities, GeoJournal 61, 309-324, DOI: 10.1007/s10708-004-4946-y.

Yang, X., Zheng, X.-Q., Lv, L.-N., 2012: A spatiotemporal model of land use change based on ant colony optimization, Markov chain and cellular automata, Ecological Modelling 233,11-19, DOI: 10.1016/j.ecolmodel.2012.03.011.

Tomislav Jogun

tjogun1@hotmail.com

mag. geogr., mag. ing. geod. et geoinf., Promet i prostor d.o.o., Dubovačka 38,

10000 Zagreb, Croatia

\section{Aleksandar Lukić $\quad$ alukic@geog.pmf.hr}

izv. prof. dr. sc, Sveučilište u Zagrebu, PMF, Geografski odsjek, Marulićev trg 19/I, 10000 Zagreb, Hrvatska

\section{Mateo Gašparović mgasparovic@geof.hr}

doc. dr. sc, Sveučilište u Zagrebu, Geodetski fakultet, Zavod za kartografiju i fotogrametriju, Kačićeva 26 ,

10000 Zagreb, Hrvatska 